\title{
8. Private Printing, Private and Government Cooperation, and the Printing Workforce
}

\section{The Private Printing Sector}

In the field of printing that was not financed or controlled by the government, production for commercial purposes provided textbooks and learning aids of all types to prepare for official examinations. Moreover, information was provided in fields of knowledge beyond those that were directly controlled by the state - for instance, merchantry, navigation (maps), medicine, and agriculture - but less for the craft trades, where skills were for the most part transmitted orally. Commercial publishers also supplied the entertainment sector, especially the theatre, with scenarios and fictional writings. Multicolour block printing was used for book illustration, calendars, and for room decoration such as New Year's pictures. And from the midnineteenth century, information on contemporary political, economic, and cultural affairs and events was also printed in newspapers and journals, using lithographic and letterpress equipment imported from overseas.

Printing for non-commercial purposes served to enhance scholarly and social prestige. The boundaries of non-commercial and commercial publishing were sometimes blurred. If collectors reprinted their valuable editions of medical texts, for instance, for the use of other scholars or a wider public and sold these books, they preferred to understand their income by sales as only a means to purchase more rare editions that they could reprint and redistribute rather than gaining mere profit. ${ }^{1}$ Religious beliefs were

1 A typical case of a gentleman-merchant who printed to enhance his prestige rather than to make profits was Pan Shicheng (c. 1804-1873), a Guangdong comprador and book collector, who between 1845 and 1851 published the collectanea Haishan xian guan congshu 海山仙館叢書 and other works. See Eminent Chinese of the Ch'ing Period, p. 6o6; Wang and Lin, 'Nan Yue xianxian'. A famous early non-profit printer was the father of the philosophers Cheng Yi and Cheng Hao, see Tsien Tsuen-hsuin, Paper and Printing, p. 381, fig. 1234; see also Ellen Widmer 'The Huanduzhai', p. 97 with a description of a philanthropist who was prompted by supernatural forces to print the medical texts in his possession. One of the most productive printer-publishers was Mao Jin (1599-1659), who is said to have published more than 600 works on over 100,00o woodblocks in thirty years, which were sold all over the country at fixed prices. But rather than accumulating profit, Mao invested the family fortune in his bookselling enterprise. See Fang Xing et al., 'Paper Making, Printing and Publishing', p. 235. 
another important stimulus for non-commercial printing. Thus, the first known examples of printed scrolls and books in East Asia contain Buddhist writings. ${ }^{2}$ Buddhists were especially eager to duplicate texts because they believed that this was a way of acquiring merit and improving their karma, and that the quantity of texts produced had a direct influence on the amount of personal merit. ${ }^{3}$ Christian missionaries had made efforts to spread their creed in China from the sixteenth century, and in the nineteenth century, the letterpresses they had imported and the fonts they had developed helped to launch mechanized printing. Christian competition in turn may have been one of the triggers for the lay Buddhist movement of the late nineteenth century, which adopted the reproduction and distribution of Buddhist texts as its foremost method of promoting its religious mission.

\section{State of the Field and Locations of Printing Workshops}

Since the 1980s and 1990s, the study of Chinese book and publishing history has been expanding in academic circles in China and abroad. ${ }^{4}$ In the People's Republic of China, important outline histories have been written by Zhang Xiumin and Zhang Shudong. The technical aspects have been most thoroughly treated in English by Tsien Tsuen-hsuin and in Chinese by Pan Jixing. In addition to these overviews, detailed studies of printing in the provinces and smaller centres are also abundant.

Japanese scholarship has traditionally been strong on the study of dating and editions, since Chinese books were acquired in Japan from an early period and in considerable quantity. A fair number of books no longer extant in China have been preserved in Japan. One of the classical studies in this respect is Nagasawa Kikuya's Wa Kan sho no insatsu to sono rekishi (The printing of Japanese and Chinese books and its history). More recently, the eminent expert of Chinese bibliography, Yoneyama Toratarō, published

2 Ledderose, Ten Thousand Things, pp. 150-152, refers to dharani rolls, several centimetres high and some metres long, that contain parts of the 'Great Dharani Sütra of Stainless Pure Light', discovered in the monastery Pulguksa in Korea, dating before A.D. 751, and of the same text, which in A.D. 764, a Japanese empress vowed to have printed in one million copies. The oldest dated printed scroll $(23.7 \mathrm{~cm}$, more than five metres long) from China is the Diamond Sūtra discovered in Dunhuang. Its colophon records the year A.D. 868. Cf. Tsien Tsuen-hsuin, Paper and Printing, p. 8.

3 Ledderose, Ten Thousand Things, p. $15^{2}$.

4 For overviews of the recent state of the field, see McDermott, Social History of the Chinese Book, 'Bibliographical Notes', pp. 263-278, and Meyer-Fong, 'The Printed World'. 
Zusetsu Chūgoku insatsu shi (An illustrated history of Chinese printing). Younger generations of Japanese scholars have concentrated on the cultural meaning transported in Chinese books. An outstanding study in this respect has been presented by Inoue Susumu in his work Chügoku shuppan bunkashi (2002) on scholars, the state, and book distribution from the beginnings of handwritten books in the first millennium B.C. to the Ming; a further important contribution to the book history of the High Qing is Okamoto Sae's 1996 study on censorship ('book prohibition' kinsho/jinshu ) in the Qing.

The field is also increasingly flourishing and gaining momentum in European languages. Recently, there has been extensive study of the previously fairly unknown activities of private printing and publishing workshops and enterprises. For the Ming and Ming-Qing transition, outstanding research has been carried out by Lucille Chia about publishing in the Fujian province centre at Jianyang (2002), by Ellen Widmer on the publishing house Huanduzhai in Hangzhou and Suzhou (1996), and by Chow Kai-wing on Late Ming commercial publishing and the way in which political control was exerted on the contents of books privately printed, especially in comparison to censorship in European countries (2006). Joseph McDermott's study on the social history of the Chinese book (2006) develops the thesis of the importance of the manuscript versus the imprint in late imperial China, which at several points draws on Inoue Susumu's previous studies. ${ }^{5}$ Imprints and manuscripts remained complementary throughout the Qing and even Republican periods, even though printing as a means of duplicating texts gained ascendance in the late Ming. ${ }^{6}$ The situation of government and private printing from the Song era up until the early Ming has been presented and analysed in a collected volume edited by Hilde de Weerdt and Lucille Chia, ${ }^{7}$ and Cynthia Brokaw and Christopher Reed brought together articles on both traditional and present-day publishing in their 2010 collection From Woodblocks to the Internet.

Important work on printing in the nineteenth and early twentieth centuries focuses on the rise of newspapers and the emergence of a public sphere, especially in Shanghai. Major achievements here have been reached by the Heidelberg project group, which has focused on the beginnings of a public sphere in China, with particular focus on the Shenbao (1872-1949),

5 McDermott, 'The Ascendance of the Imprint', p. 57.

6 Ibid., p. 92. Cf., for instance, the fact that the Court Gazette was also sold in a handcopied edition throughout the longest part of the Qing period.

7 De Weerdt and Chia, Knowledge and Text Production in an Age of Print: China, 900-140o. Leiden: Brill 2011. 
one of the first commercial daily newspapers in China, founded in 1872 by the British entrepreneur Ernest Major (1841-1908).

Barbara Mittler, Natascha Vittinghoff, and Andrea Janku have studied the rise of the public sphere and the role and self-evaluation of the intellectuals in the political upheavals of the late nineteenth and early twentieth century in monographs and, together with other authors, in contributions to a volume edited by Rudolf $\mathrm{G}$. Wagner. ${ }^{8}$ Other important research on publishing in Shanghai includes the early study by Jean-Pierre Drège on the Commercial Press between 1897 and 1949 and, more recently, Christopher Reed's inquiry into the rise of Chinese 'print capitalism' in the late Qing and early Republic of China.

Research on popular multicolour ornamental printing has been presented by John Lust in an overview in Chinese popular prints and in a monograph on ornamental printing in Shandong by James A. Flath. Gabriele Goldfuss has inquired into the religious printing activities of the lay Buddhist movement around Yang Wenhui (1837-1911) in the late nineteenth century.

In this impressive range of scholarship that looks at book production from economic, technical, political, and cultural perspectives, the most recent highlight is Cynthia Brokaw's exploration of printing and publishing in Western Fujian, a region even more remote than Jianyang in the same province, which was researched by Lucille Chia. Brokaw directs our attention to the Sibao publishers, who were hardly ever acknowledged in the standard Chinese elite-oriented printing histories. Their products of average or low quality were what most people could afford, such as primers for reading and writing, fiction, and medical handbooks. This research shows that block printing, which Shanghai book and press historians were to dismiss as marginal in the twentieth century, was carried out on the periphery until the 1940s. In fact, as Goldfuss has shown, if printing blocks were not recycled for purposes such as heating or for paving ways and roads, and if they survived political upheavals, they could be used for printing in the late $1980{ }^{9} .^{9}$ In 2006, UNESCO declared the Chinese engraved block printing technique to be an Intangible Cultural Heritage that deserves to be safeguarded. ${ }^{10}$

8 Rudolf G. Wagner (ed.), Joining the Global Public.

9 Goldfuss, Vers un bouddhisme, p. $5^{1} \mathrm{ff}$, and fig. 2, 5-6 with photographs of the 'Sutra carving site' (Kejing chu 刻經處) in Nanjing taken in the early 1980s, which show printers inking the woodblocks and binding the sutra texts.

10 The list 'Guowuyuan guanyu gongbu [...] Fei wuzhi wenhua yichan minglu', dated May 2006, mentions the techniques of block printing sites in Yangzhou, the Jinling Sutra Printing Site, and the Dege Sutra Printing House in Sichuan Province (as numbers 429/VIII/78 to 8 o respectively) as protected intangible cultural heritage. See also 'Jinling kejing yinshua jishu'. 
Like the other branches of handicraft manufacture, the printing sector during the Qing era followed the pattern of rising commercialization and expansion of manufacturing of the late Ming. After a short lull during the Ming-Qing transition, the production of printing also spread out to rural and peripheral areas. ${ }^{11}$ Some important commercial publishing sites in the late Ming (sixteenth and seventeenth centuries) were Nanjing, Suzhou, and Huzhou in Jiangnan; Yangzhou in Northern Jiangsu; Hangzhou in Zhejiang; Huizhou in Anhui; and the Jianyang centres of Masha and Shufang in Fujian. In the Ming-Qing transition, Jianyang as a centre of printing suffered and did not recover. Nanjing and Hangzhou lost their leading positions, and Peking with its Liuli chang district rose to primacy. ${ }^{12}$ Zhang Xiumin lists only thirteen commercial publishing houses in Peking in the late Ming period, while 38 commercial printers in Nanjing are known. This ratio was turned around during the Qing era, when 112 publishing houses and bookstores existed in Peking, and only thirteen in Nanjing. In the provinces, starting from the Kangxi era, Sichuan had ten large commercial houses in Chengdu and several establishments in Chongqing. Nevertheless, these figures may be just the tip of the iceberg. The Jiangnan printing industry - including all publishers not only in Nanjing but also Suzhou, Yangzhou, and Hangzhou - was still prolific even in the eighteenth century. In the nineteenth century, the Jiangnan metropolis Shanghai again overtook Peking and, together with Canton, became the first place where mechanized printing machinery was operated.

Canton became a centre of printing in the mid-Qing. It was a place where much information on overseas powers and countries arrived. Reformers and statecraft thinkers from before and after the Opium Wars published their writings in the jingshi wenbian collections and monographs such as the Haiguo tuzhi (Illustrated treatise on the maritime kingdoms). At least 23 printing shops existed from the 1850 os until the first decade of twentieth century. Two more towns in the vicinity of Canton had print shops of more than local importance: the market town Foshan and the more rural Magang in Shunde district. Foshan, a busy market town which was also a centre for ceramics and the iron industry, had at least twelve publisher-printers, more than any other city in Guangdong with the exception only of Magang, where female block cutters practiced their low-wage trade. ${ }^{13}$ For the market town of Xuwan, a printing centre in Jiangxi, there are figures of about 47 individual 
printing and publishing shops. According to Brokaw, Xuwan and Magang had the single greatest output of block printings. In north China, Ji'nan and Liaocheng were important locations for printing, as both were strategically located near the north-south traffic artery of the Grand Canal. Yuechi county in eastern Sichuan was a rural region where farmers practiced block cutting as a subsidiary craft in the eighteenth and nineteenth centuries. They supplied the urban book market in Chengdu and Chongqing but also had their own direct distribution channels. ${ }^{14}$ The rural centres of printing in South China were most often located in areas that also had a prolific paper manufacturing industry. ${ }^{15}$

The art of multicoloured woodblock printing used for house decoration, especially during New Year (nianhua), in the early and mid-Qing era was concentrated in the three largest artistic centres of Suzhou (in the Taohuawu district); Yangliuqing in Hebei, fifteen kilometres west of Tianjin; and Mianzhu in Sichuan, about one-hundred kilometres northeast of the provincial capital Chengdu. ${ }^{16}$ On a smaller scale, ornamental block prints were produced in many locations throughout the Qing empire. ${ }^{17}$

\section{Output of the Printing Industry}

In the private printing sector, it is difficult to make a clear division between the concepts of 'publishing house', 'print shop', and 'bookstore'. As a rule, the publishing house (shufang, literally book-workshop) both produced and distributed books.

So far, much doubt remains about the aggregate output of these rural and urban centres of printing and publishing. One estimate that is frequently quoted in the literature was made by Yang Jialuo: among the 253,00o titles registered in official historiography and bibliography from the Han to the Qing era, about half of the output- over 126,00o titles, probably also including manuscripts - are attributed to the Qing, ${ }^{18}$ yielding a yearly average of 471

\footnotetext{
14 Ibid., p. 12.

15 For an excellent, comprehensive study on papermaking in Sichuan, see Eyferth, Eating Rice From Bamboo Roots.

16 John Lust, Chinese Popular Prints, p. 47, 66, 8 o.

17 Lust, Chinese Popular Prints, p. 86, mentions one to three minor centres in every province, and James Flath in The Cult of Happiness, p. 12-13, gives details on six further locations in the North China 'aesthetic region'.

18 Tsien Tsuen-hsuin, Paper and Printing, p. 19o, fn. f, citing Yang Jialuo楊家駱, 'Zhongguo gujin zhuzuo mingshu zhi tongji' 中國古今著作名數之統計 (Statistics of old and new Chinese book titles), in Xin Zhonghua 新中華 (The New China Fortnightly), 1946, vol. 4, p. 7 .
} 
titles per year for the 267 years of the Qing dynasty. Not all Chinese book historians agree with this figure. At present, the estimates for the Qing dynasty range between $70,000 / 80,000^{19}$ and $200,000^{20}$ titles. This result does not impress European bibliometricians, who point to annual averages of book production between 1751 and 1800 on a scale of, for instance, 2,300 in the regions now known as Germany and 3,100 in France, or 12,500 for entire Europe including Russia. ${ }^{21}$ The low-end estimates for China are based on information in various Qing bibliographies, which tend to understate or ignore books beyond the scope of state orthodoxy. Thus, Buddhist writings and local compilations, especially the great number of genealogies, were often disregarded. As we see from Brokaw's study on Sibao, the sales volume of one of the largest Sibao publishing houses in the early twentieth century, when mechanized printing started to replace the handicraft trade, amounted to 8,000 sold copies of 250 titles per year. These are most certainly not considered in any of the above estimates. In the heyday of Sibao publishing in the Qianlong and Jiaqing eras, 46 such publishing houses were founded. ${ }^{22}$

The total number of copies of existing 'ancient books' (printed and handwritten before 1912) has been assessed at between 35 and 50 million. ${ }^{23}$ The number of titles produced between 1912 and 1949 has been estimated at 68,000 titles, which amounts to about 1,80o per year. ${ }^{24}$

Looking at the issue from the consumer side is difficult because no systematic surveys of literacy rates were conducted before the twentieth century, and observations by Chinese and Western observers between the seventeenth and the nineteenth centuries diverge sharply. The most generous estimate of Qing dynasty literacy rates has been made by Evelyn Rawski. From scattered evidence, she has concluded that during the Qing era about 30 to 45 percent of the men and two to ten percent of the women could read and write. ${ }^{25}$ For nineteenth-century rural Guangdong, she estimated a male

19 Wu Feng 吴枫, 'Zhongguo guji shuliang shulue’ 中国古籍数量述略 (A brief account on the quantity of Chinese old books), in Wu Feng xueshu wencun 吴枫学术文存 (Collected works of Wu Feng), Beijing: Zhonghua shuju 2002. The author is grateful to Professor Gao Xuan 高瑄, Vice Director of Tsinghua University Library, Peking, who provided this information and the following data on Chinese estimates.

20 Wang Shuwei 王树伟, 'Woguo guji zhi duoshao' 我国古籍知多少 (How many old Chinese books exist?), in Baike zhishi 百科知识 (Encyclopedic knowledge), 1981, no. 12.

21 Buringh and van Zanden, 'Charting the 'rise of the West", p. 44; van Zanden, 'De timmerman', p. 117/118.

22 Brokaw, Commerce in Culture, p. $3,8$.

23 Ancient Collection Division, 'Current situation' and information by Gao Xuan.

24 Reed, Gutenberg, p. 298, note 8.

25 Rawski, Education and Popular Literacy in Ch'ing China, pp. 22-23. 
literacy rate of 40 to $5^{\circ}$ percent, and in Canton city even 89 to 90 percent. Li Bozhong , who discusses Rawski's data, estimated a maximum literacy rate in the region of the Yangzi Delta of 30 percent for both genders. ${ }^{26}$ Other scholars are more sceptical and have estimated male literacy in the range of 20 to 25 percent. Opinions on what 'literacy' actually means are also divided. According to Li Bozhong, 'being literate' implies knowledge of at least onethousand characters and 'half-literate' about 500 to 600 characters, ${ }^{27}$ but scholars such as Wilt Idema have defined 'moderate literacy' as starting with a knowledge of about 2,000 characters. ${ }^{28}$

Literacy does not necessarily mean that a person will buy books. However, in view of the estimated $5^{1}$ to 102 million literate people in 1800 or 60 to 120 million in $1900,{ }^{29}$ even the highest estimate of $5^{\circ}$ million extant books (as of 1912) seems a low rate that may imply that much book production was not recorded by Chinese bibliographers.

Price trends for books were decreasing throughout the Qing era and varied broadly according to the quality of collating and proofing, charactercarving, and materials used for printing and binding. The sales prices that Liu Qiang states for the Wuying dian books ranged from 12.46 tael for the rhyme dictionary Peiwen yunfu (106 chapters), printed in 1711; 5.148 tael for the 'Regulations and precedents of the Ministry of Personnel' Libu zeli ( 52 chapters) printed around 1800; and 6.721287 tael for the Peking city gazetteer Rixia jiuwen kao (160 chapters), printed in 1778 . The last quoted price at that time bought 268 jin (ca. $160 \mathrm{~kg}$ ) of white wheat flour. ${ }^{30}$

Cynthia Brokaw quotes book prices for the low end of the production scale and at a time when prices had fallen, mainly due to the decline of woodblock prices since the Jiaqing era. The cheapest items on the Sibao merchants' account books in the last decades of the Qing and in the early years of the Republic were primers like the 'Three character canon' Sanzi jing for 0.005 tael, an edition of the six-chapter 'Three-hundred collected Tang poems', or a simple annotated 'Book of Changes' or 'Classic of History' for 0.03 tael. The most expensive item was a sixteen-chapter collection of ghost stories, Liaozhai zhiyi, with a wholesale price of 1.1 tael and a retail

28 Brokaw, Commerce in Culture, pp. 562-565.

29 Assuming an optimistic literacy rate of 30 percent and a pessimistic rate of 15 percent respectively for a population of 341.6 million in 1800 and 400 million in 1900 . For population figures, see Angus Maddison, Chinese Economic Performance in the Long Run, p. 169, 'Table D.1. Chinese Population, 5o AD-1996'.

3o Liu Qiang, 'Qing Wuying dian', p. 276. 
price of 1.32 to 1.76 tael. ${ }^{31}$ About half of the titles cost 0.1 tael or below. In view of wages in the late Qing period, the low-priced books should have been affordable for families whose income was at least partly in monetary wages, while the palace editions remained luxury editions for the very wealthy or for state institutions.

If the output of the government printeries is seen in relation to the overall output, even in Yang Jialuo's figures, at 600 for the central government and 1,00o for the printeries of the provincial governments, this accounts for but one percent of the titles. However, the comparison is skewed because the voluminous encyclopedia Gujin tushujicheng is only counted as one title. The percentage would increase significantly if we took court and provincial gazettes into account, but in this case we would also have to include the output of the commercial newspapers and journals published especially in the treaty ports. Leaving newspapers and court gazettes aside, it is still evident that the output of government printeries comes to but a fraction of the total production of the printing industry in the Qing period.

\section{Mechanization in the Printing Industry in the Late Qing and Early Republic}

From the beginning of the nineteenth century, as political crises of unprecedented scale shook the empire and competing value systems appeared in the form of Christianity and - for two decades - the Taiping ideology, the printing industry boomed and diversified. Already before the Opium War, the London Missionary Society had started to develop Chinese letterpress printing and letter-casting machines (relief media) as well as planographic media (lithography) in Southeast Asia and in the city of Canton. The postOpium War treaties of Wangxia (1844) and Tianjin (1858) guaranteed overseas powers the freedom of Christian missionary activity in China. Consequently the printing activities of both Protestant (the London Missionary Society, the American Presbyterian Mission Press) and Catholic (Jesuit) groups intensified. The Protestant missions preferred letterpress relief media, while the Catholics favoured planographic printing (lithography and collotype). ${ }^{32}$

Copperplate engraving (intaglio) had first been introduced in the Kangxi era and from 1712 had been applied by Jesuit missionaries at court for map 
making. ${ }^{33}$ The Qianlong emperor was particularly interested in the artistic and graphic qualities of this medium. In 1765 , he ordered from the French royal academy for painting and sculpture in Paris a series of sixteen copperplate engravings of the military expeditions to Turkestan to be executed on the basis of the paintings of his court painters Giovanni Castiglione, Denis Attiret, Ignatius Sichelbarth, and Jean-Damascène Sallusti. The offprints and copperplates were delivered in 1774 . Thereafter, the series of military expeditions and suppressions of uprisings were all glorified with large-size copperplate engravings, and this time executed by Chinese designers and engravers. ${ }^{34}$ Around 1787 , the buildings in European style of the imperial gardens Yuanming yuan were also, upon imperial order, depicted with this foreign technique by Chinese artists who had been trained by Castiglione. ${ }^{35}$ The last series of copperplates showing battle scenes depicts the subjugation of the rebellion by Jehangir in Eastern Turkestan between 1825 and 1828 and was designed in $1828 .{ }^{6}$ After a lapse of a few decades, mechanized copperplate engraving was reintroduced in the Jianghai Customs Printing Office in Shanghai but more importantly in the printery of the Ministry of Finance for banknotes, stamps, and government seals. ${ }^{37}$

Private, secular printing firms like Ernest Major's enterprises used letterpress for newspaper production and lithography for illustrated magazines and reprints of classical Chinese literature.

Yet before the turn of the twentieth century, most book printing outside the treaty ports was still done in woodblock carving.

The rise of the modern printing industry has been described in detail by Christopher Reed, who has shown that in the last thirty years of the Qing dynasty, lithography dominated over the letterpress in output and popularity..$^{8}$ However, after the 1890 os, letterpress typography began to replace lithography; by the early twentieth century, both types of mechanized

33 The technique was introduced by the Jesuit Matteo Ripa. The first maps were engraved in 1712 and 1719, and later under the Qianlong emperor in 1775. Helen Wallis, 'Die Kartographie der Jesuiten am Hof in Peking', p. 121.

34 See the catalogue of the exhibition 'Europa und die Kaiser von China' with the introduction by Müller-Hofstede and Walravens, 'Paris-Peking', pp. 163-172, for the illustrations of the expeditions to Jinchuan in Sichuan (1775/76), Taiwan (1786/87); Annam (1789/90), against the Gurkhas in Tibet (1793-1799) and the ethnic uprisings of the Miao in Guizhou, Hunan, and Sichuan (1798-1803) and Wädow, 'Die 'Schlachtenkupfer' aus der Regierungsdevise Qianlong'.

35 Jean Paul Desroches, 'Yuanming yuan: Die Welt als Garten', p. 124.

36 Walter Fuchs, 'Schlachtenkupfer der Kienlung- und Taokuang-Zeit', p. 119.

37 Reed, Gutenberg, pp. 28/29, table 1.1 'Western print media in China, 1700-1913', p. 65 .

38 Reed, Gutenberg, p. 121 and p. 327, note 124. On p. 126, however, he gives the figure of 94 lithographers. 
printing largely replaced woodblock printing - at least in Shanghai. Furthermore, not only were Western printing machines imported to China starting from the 1870s, the machinery was also first repaired and later built domestically. Between 1914 and 1932, Shanghai was the most important Chinese centre of printing machinery production that also exported to Southeast Asia and even to Japan. ${ }^{39}$ Domestic printing machinery makers only emerged in the period after the fall of the Qing, but it shows the vitality and adaptability of the Chinese manufacturing sector. ${ }^{40}$

As Brokaw has shown, in the periphery beyond Shanghai, block printing was still practised, if with decreasing profits, until the 1940 s..$^{41}$ Yet even in a former treaty port, Qingdao - with a population of over $400,000^{42}$ and several newspaper publishers, universities, and institutes of secondary education - printing and character carving was exercised as a handicraft trade in the 1930s. Only every one in a thousand persons was engaged in this sector, but within the handicrafts in Qingdao, printing ranked fifth in respect to households and persons employed (see Table 34 and Table 35). We have no indicators as to the relation of handicraft (block) printing and mechanized printing in Qingdao. According to a nationwide estimate of the net production value of handicrafts within the entire manufacturing sector, the share of handicrafts in the total production value of manufacturing in 1933 was still 72 percent. However, in the printing sector, mechanization had advanced faster, with the percentage of the net production value of handicrafts at only $45 \cdot 3 \cdot{ }^{43}$

In less industrialized inland cities, mechanized printing was probably less advanced, but demand for products of the 'information industries' may also have been comparatively lower than in Qingdao, for instance, where several universities and institutes of secondary learning were based. At any rate, even in early 1930s Qingdao, handicraft printing and letter

39 Ibid., p. 136.

40 Ibid., p. 135 .

41 However, even in Shanghai in the 1890 s, 'printing from blocks is still done with advantage whenever a larger work meets with continuous demand, though only a small number is needed, perhaps some hundred copies, per year.' See Reed, Gutenberg, p. 320, note 32.

42 For the population figures of Qingdao, see Cui Yuting, 'Kangzhan yiqian Qingdao', p. 145.

43 'Yijiusansan nian Zhongguo shougongye chanzhi zhan gongye chanzhi de bizhong guji' 一九三三年中国手工业产值占工业总产值的比重估计 (Estimates of the relation of the net value of Chinese handicraft production to the total net industrial production value), in Peng Zeyi, Zhongguo jindai shougongye, vol. 3, pp. 814-815. Peng quotes here the figures given in Wu Baosan et al. (eds.), Zhongguo guomin suode (China's national income), 1933, vol. 1, p. 64, 65, and 66, with (a very slight) modification in Wu's Zhongguo guomin suode 1933 xiuzheng, pp. 135, 140, and 142 . 
carving still could feed the artisans and was moderately popular as a career choice for young people considering learning a craft, probably also for the reason that little capital was necessary to start up a shop of one's own (see Table 35).

In Peking, according to the city gazetteer of 1939, about 30 lead letterpress printers and 500 smaller and larger lithographers operated their business with a workforce of about 10,000. About 2,000 of them worked at the printery of the Ministry of Finance. The section on printing states that character carving was no longer practised in commercial enterprises but was still done in schools, churches, and newspapers. ${ }^{44}$ However, the section on book and rubbings informs us that 'formerly there were several dozen of character carvers in Peking. They first all came from Nanjing, only later did they take on North Chinese apprentices. At present almost all the old shops have been closed down. Among those who persisted, the Wenkai studio is best known. [...] It often employs more than one hundred people. The other shops engage between seven and eight or one to two carvers.' Bookbinders, character copyists, and specialists for taking ink rubbings from metal or stone are also mentioned. But the print-related handicraft trade that still employed the most workers was the paper mounting of calligraphic or painting scrolls. 1,500 paper mounters are reported for Peking. The trade, like character carving, was first practised in Peking by Jiangnan artisans from Suzhou but was later mastered by Northern workers. ${ }^{45}$

To conclude, although mechanization started in the 1870 os and took off in the second decade of the twentieth century, it did not immediately push the handicraft sector from the market. Due to the huge increase in demand for information, education, and entertainment encoded in print media, the craft sector survived for several decades thereafter.

\section{The Relationship of Government and Private Printing}

The censorship of books was carried out most severely and systematically in the Qianlong era in connection with the compilation of the collectanea Siku quanshu. Recent scholarship has pointed to the emphasis by the Qianlong emperor and his central government upon censorship of anti-Manchu writings, the eagerness of officials to find suspicious books in order to gain rank and prestige, and the compliance of the scholarly elites with this 
policy. ${ }^{46}$ The monitoring activities had consequences for publishers. Zhang Xiumin refers to 'over 120 cases' of censorship in the Kangxi, Yongzheng, and Qianlong eras and states that, in the larger initiatives of censorship, not only authors but also artisans could be implicated ${ }^{47}$ One particularly drastic case is reported from the Kangxi era, when in the year 1663, the author of an indicted 'History of the Ming Dynasty', Zhuang Tinglong, was posthumously punished by having his corpse dug up and burned. Those who had edited, distributed, sold, and bought the work - as well as Tang Dafu, who had carved the blocks during a period of five years, Li Xiangfu, who had printed forty copies of it, the bookbinder, and the porter of the blocks, altogether seventy (and in another version, 120) persons were sentenced to death and executed in Hangzhou. ${ }^{8}$

Other scholars have assessed the direct impact of the 'literary inquisition' of the 1770 as less severe. For one, the suspect books were more often issued by private, not commercial publishers, and thus the range of persons involved was more confined. ${ }^{49}$ Moreover, if character carvers, printers, or sales agents were illiterate, which occurred now and then, their sentences were mitigated.$^{50}$ The blocks of the incriminated books would often be destroyed, but sometimes the emendation or deletion of the passages offensive to the emperor and his dynasty was an acceptable alternative. ${ }^{51}$ According to a report to the throne from the year $1781,52,480$ woodblocks of seditious books had been broken up and recycled as firewood. Since two pages of a book are carved on one block, the forms for at least one hundred, but more likely several hundred books, were destroyed in this process. Books were burned, too, but absolute control could not be achieved; indeed, some of the works on the 1782 index could still be found in the twentieth century. ${ }^{52}$ The censorship focused mostly on scholarly works in the field of history, and to some extent lexicography; examples of works of entertainment are not recorded, so it appears that commercial publishing was not greatly affected by the prohibitions. Following the model of the preceding dynasties, cultural politics during the Qing era promoted an education that was focused on

47 Zhang Xiumin, Zhongguo yinshua shi, p. 544.

48 Ibid., pp. 757-758.

49 Brook, 'Censorship', p. 181.

$5^{0}$ Ibid., p. 183, refers to a reduction of the sentence of flogging from one hundred to eighty blows, as well as exemption from three years of banishment for the illiterates engaged in book production.

51 Brook, 'Censorship', p. 191.

$5^{2}$ Guy, Four Treasuries, pp. 171, 194. 
the students' participation in official examinations on various levels, from district and provincial to the level of the capital. Scholarly status greatly enhanced one's social prestige. Whoever could afford the tuition fees and the books (and was not dependent upon family male labour power for more basic economic pursuits) could allow their sons to study in preparation for a degree in one of the levels of the examination hierarchy.

The road was theoretically open for all males except those with 'debased' status, but artisans, for instance, could rarely take it due to financial reasons. Until the mid-eighteenth century, the canon of books to be mastered for analysis and exegesis in official examinations covered the Confucian classics, historical works, political administration and decision-making, and jurisprudence. After 1756, the composition of a poem was demanded in addition to essays and exegetical answers to questions on moral philosophy, while the legal question was eliminated from the examination questionnaires. ${ }^{53}$ Only a limited percentage of the population participated in official examinations: it has been estimated that in the late Qing period 1.6 to 1.9 percent of the total population took part in the examinations. By 1800 , a quota of over two million examination candidates together with about 750,00o degree holders who had already attained scholarly status were channelled into this specific type of elite learning by the decisions of the central government. ${ }^{54}$

Knowledge of science, medicine, and technology was required only at the general level that was necessary for administrative decisions. Expertise in these fields was not tested in the highest examinations that were held at the capital. Nevertheless, Qing emperors and scholar-official elites, especially in Jiangnan, were aware of the importance of knowledge of precise studies, especially mathematics. The early Qing emperors Shunzhi and Kangxi employed Jesuit missionaries at court who brought recent European knowledge of astronomy, mathematics, geography, cartography, and, to a certain extent, mechanics, to the personal attention of the rulers and the Chinese scholars. In the eighteenth century, proto-scientific research was exercised outside the court in Jiangnan scholarly communities. It was linked to 'evidential research' (kaozhengxue), which had previously for the main part involved philological scholarship. As long as these endeavours remained apolitical, the Qing state did not interfere with the evidential researchers. 55

53 See Elman, 'The Social Roles of Literati', p. 367, 'The Format of Provincial and Metropolitan Civil Examinations, 1646-1756', p. 374 for the content of boyhood education, p. 409 for the 'Reformed Format of Provincial and Metropolitan Civil Service Examinations, 1757-1787', p. 413 for the 'Reformed Format of Provincial and Metropolitan Civil Service Examinations, 1793-1898'.

54 Elman, 'The Social Roles of Literati', p. 370.

55 Ibid., p. 425 . 
Since only the smallest part of these prospective and already successful candidates could actually attain a post in administration, one of the ways of putting one's knowledge to good use was by teaching in state or private schools and academies or by opening a bookstore-publishing house. As literacy spread from the early nineteenth century on, basic writing and calculating skills were taught on a wider scale than before ${ }^{56}$ and teaching materials were also printed and distributed by lowbrow publishing houses such as those based in Sibao or Xuwan at affordable prices. ${ }^{57}$

The state did not obstruct the publishing and printing activities of the private sector if it kept clear of criticism of the dynasty, such as downright condemnation of the Manchus as 'barbarians' or, more subtly, referring to the Qing emperors and empresses by their personal names rather than using the obligatory substitute characters. Two examples, one large and one small, illustrate the relation of the central government and the private sector after the decline of printing activities at the Wuying dian in the mid-nineteenth century. In the first case, the central government and the court privatized the reproduction of what had once been the essence of Qing dominance over the canon of knowledge in the empire. In the second case, printing the internal rules and regulations of court life was also outsourced.

On imperial order, the encyclopedia Gujin tushu jicheng was reprinted twice in the late Qing, once by letterpress and once in lithography. The court had 1,500 copies printed of the letterpress lead type edition by a company established specifically for this purpose that went by the name of 'Tushujicheng Lead Type Publishing Company' (Tushujicheng qianyin shuju). It is preserved in many libraries worldwide, which, somewhat confusingly, date it to $1884,{ }^{8}$ but the printing dates 1885 to 1888 seem more plausible. ${ }^{59}$ The publishing company was a subsidiary of Dianshizhai, which belonged

56 Elman, 'The Social Roles of Literati', p. 370.

57 The publishers of Xuwan, according to Brokaw, Commerce in Culture, p. $53^{8}$, were mostly 'failed' scholars or low degree holders. Brokaw, op. cit., p. 516, has calculated that during the late Qing, a modest selection of twenty elementary schoolbooks by the Sibao publishers for the examination curriculum would cost between 0.1728 and 0.2580 tael.

$5^{8}$ According to the digital library catalogues of the Academia Sinica, Taiwan, the Japanese Union Catalogue Nacsis, the Taiwan National Library, and the Beijing tushuguan (the Chinese National Library), '1884' is presumably the year when the project was started. According to the Beijing tushuguan, the imprint expressly says: 'in the summer of the year Guangxu jiashen (1884), the Shanghai Tushu jicheng lead type edition publishers assembled stocks for the reprint' 光绪甲 申年夏上海图书集成铅版印书局集股重印. The National Library lists another lead-type edition by the Shanghai Tushu jicheng letterpress publishers of Guangxu 30 (1904). No information was available on this reprint.

59 Giles, Alphabetical Index, p. xix; Reed, Gutenberg, p. 116. 
to the Shenbao group that the American entrepreneur Ernest Major had founded and at that time still owned. ${ }^{60}$

Whether lithographic rather than letterpress printing is more aesthetically pleasing to the Chinese remains unresolved, ${ }^{61}$ but obviously the government wanted to commission an additional, more presentable lithographic reprint and eventually gave out another order to Tongwen press, the largest Chinese-owned lithographic enterprise at the time.${ }^{62}$ The initiators from the Council of Foreign Affairs (Zongli yamen) intended to use it also as a gift in international diplomacy, presumably to show the scope of Chinese learning. The court covered the entire sum of about 350,00o tael for one hundred copies, which were printed and published as a revised edition with emendations, totalling 1,672 volumes $(c e) \cdot{ }^{6}{ }^{6}$ The production process lasted from 1892 to $1894 .{ }^{64}$ Part of the edition was to be sold for 3,500 tael per set, but after several years, a considerable number of copies remained on stock, taking up much space. After 1901, the government presented copies to the provinces $^{65}$ and also to foreign heads of states and institutions. ${ }^{66}$

From the perspective of the government and court, the contrast to the Kangxi/Yongzheng project must have been striking. Back then, applying a comparatively rare but sophisticated technology and collecting the latest information on the widest imaginable scope of topics including knowledge of Western mathematics, astronomy, geography, and armament provided by missionaries, the court produced this sum of learning on its own in a

60 Reed, Gutenberg, p. 104.

61 See Rudolf Wagner's critique of Reed's thesis that early lead-type printing before ca. 1900 could not satisfy Chinese aesthetic demands. Wagner, 'Gutenberg' (Chapter 1); Reed, Gutenberg, p. 27 .

62 Reed, Gutenberg, pp. 115-117.

63 The memorial with the cost estimate for the project states that the original Kangxi edition to be used as an exemplar for the reprint cost 13,00o tael. 'Zhupi Guangxu Shiliu nian shi yue shisi ri junjichu zoupian’ 硃批光緒十六年十月十四日軍機處奏片 (Memorial note of the State Council, Guangxu 16/10/14, with vermilion rescript), in Zi Ye, 'Qing ting shiyin', p. 62.

64 Zhang Xiumin, Zhongguo yinshua shi, p. 592.

65 'Zhupi Jiangxi xunfu xie'en shangci Gujin tushu jicheng pian' 硃批江西巡撫謝恩賞賜《 古今圖書集成》片 (Note by the Jiangxi governor on the grateful receipt of the Gujin tushu jicheng, with vermilion rescript, [Guangxu 27, 1901]), in Zi Ye, 'Qing ting shiyin', pp. 62-63. Zi Ye mentions that this is the earliest of twelve notes by provincial governors on the receipt of the encyclopedia.

66 One set was donated to the China Society of London and given on loan to the Library of the University of Cambridge, see 'Introduction to the Chinese Collections'. Another one was presented to the American president Theodore Roosevelt, who had it stored in the Library of Congress, see Zi Ye, 'Qing ting shiyin', p. 63. In 1902, Columbia University in New York also received one set. See Reed, Gutenberg, p. 325, fn. 103 . 
veritable 'palace edition'. Now, in an effort to conserve Chinese learning that must be understood as part of the self-strengthening movement, the project had to be outsourced to 'merchants ${ }^{\prime 67}$ and earlier had even been reproduced by a foreign-owned printing company.

A printing project much smaller in scope concerning subject matter particularly important for everyday life at the Qing court was the revision of the 'Imperially endorsed interior court regulations' (Qinding gongzhong $z e(i)$. The accounts book of the project are preserved in the First Historical Archives. They are not dated, but from all the information available about court regulations, we can assume that the book contained the 1884 regulations. In the bibliography of the works of the Imperial Household Department, this edition as well as its predecessor of the Tongzhi years (1862-1874) is attributed to the Wuying dian. ${ }^{68}$ However, from extant documents we see that these regulations - which concern, for instance, the conduct of all courtiers and eunuchs, and the treatment of palace women - were commissioned to printers and character carvers from a commercial printshop, Zhuanyun zhai (Carved cloud studio) ${ }^{69}$ at the book and antique centre Liuli chang. This printing and character carving workshop printed all Peking pawn certificates (dangpiao). Apparently it held this monopoly by customary agreement among the pawnshops. ${ }^{70}$ Five printers with their materials, including the blank printing blocks, were sent to execute the job in the palace..$^{71}$ They finished after 115 days, and two of them stayed on for another eleven days for corrections and emendations. Seventy more workday units (gong) were necessary for printing and binding. ${ }^{2}$

It remains a puzzle as to why of all texts, the court regulations that are most intimately related to the personal life of emperors, eunuchs, and court women were entrusted to outside printers at a time when, judging from the other extant accounts, the Wuying dian was not yet quite defunct. The archival records

67 This designation is preserved in the memorial of the State Council, which states, 'We, the ministers, have found out that the Shanghai merchants are the most familiar with lithography' 'Zhupi Guangxu Shiliu nian', in Zi Ye, 'Qing ting shiyin', p. 61.

68 Qingdaineifu, pp. 236/7.

69 Archival record at the First Historical Archives, Neiwufu zeliguan 内務府則例館 (Regulation and precedent office of the Imperial Household Department) 23, Fuwen 附文 1 to 3, undated. 70 Wang Yongbin, 'Dong hengzhao dangpu'; 'Beijing de qianshi jinsheng.' Besides pawn certificates, Zhuanyun zhai also printed works of entertainment like the scenario book Guwu $l u$ 顧誤錄, an edition of 1851 .

71 The document Neiwufu zeliguan 内務府則例館 23, Fuwen 附文 (Appended note) 1 mentions 'additional food money for printers that are sent to the Palace' and 'wages for those who transport the blocks into the palace.'

72 Neiwufu zeliguan 内務府則例館 23, Fuwen 附文 3, p. 1. 
show that the entire text was carved, printed, and bound by the Zhuanyun zhai personnel. This suggests that the Wuying dian at this time did not have enough qualified manpower at its command for even for this relatively minor project.

Both printing projects outlined above - the huge imperial encyclopedia and the short handbook of court behaviour - show that not only the central government but also the court administration had already relinquished the idea that only - or at least mainly - imperial craftsmen upon palace precincts should execute the printing of the texts that ensured the emperor's control and sponsorship of learning in the whole Qing realm and the conduct of his thousands of personal servants in the Forbidden City.

\section{The Workforce Employed by the State and Private Workshops}

The locations where printing blocks were prepared, characters carved, and books were printed and bound ranged from the centre of imperial power to rural surroundings at a distance of thousands of kilometres from Peking, where characters might be carved under the open sky. The workforce was as varied as these settings. However, also within the craft - or art - of block printing, the required knowledge and skills differed widely. This involved writing out the model transcript in beautiful calligraphy onto sheets that were pasted in reverse on the printing blocks, carved out in relief, brushed with ink, covered with the pages, pressed, taken off, dried, controlled, and thread-bound into flexible volumes. Accordingly, the qualifications and payment of the craftspeople varied as well.

\section{Artisans in the Palace Printery Wuying dian}

In the imperial printery, students of the imperial academy would write out texts that were subsequently processed by artisans in decreasing order of qualification. During the longest period of its activities, highly skilled artisans were employed at the imperial printery, but here, too, a strict hierarchy applied to the various stages of the printing process. ${ }^{73}$ As one

73 For information on the staff of the Wuying dian, both Lu Shaw, Imperial Printing, pp. 9-11 and Liu Qiang, 'Qing Wuying dian', pp. 267-269, refer to the Guangxu edition of the Collected Statutes (Huidian, chap. 89, 98; Huidian shili, chap. 1045, 1173), but vary slightly. Liu Qiang concentrates on the fuller staff after 1778 and mentions more subordinate sections and officials of intermediate position than Lu Shaw. 
of the agencies of the Imperial Household Department, it came under the general supervision of a high-ranking member of the imperial clan. Its two main sections were those of the Overseer of Works (jianzao chu) and of Proofreading (jiaodui shuji chu). The section of the Overseer of Works was responsible for printing books and tracing the emperor's handwriting for engraving. It had several subordinate sections that respectively functioned for the entire time span of this institution or only for certain periods. These were the copper type storehouse (tongzi ku) for the copper type used in the Gujin tushu jicheng project; a bindery (shuzuo) within the Wuying dian, in the south-eastern aisle; ${ }^{74}$ a printery (shuayin zuo), where the transcripts for block printing were copied and the blocks were prepared and cut - initially the blocks were cut only within the Wuying dian, but after 1860, two additional exterior sites were used; ${ }^{75}$ the paper-folding section (zhepei zuo); the house for wooden types ('assembled gems' juzhen guan) for Jin Jian's wooden movable type project at a location outside the palace gate Xihua men, not far from the Wuying dian; a section for tracing the imperial handwriting (yushu chu); ${ }^{76}$ and several storage, financial, and other administrative subsections. In its fullest expansion, it had regular positions for about twenty leading staff, thirty subordinate clerical jobs, and eighty to ninety artisans. The Section of Proofreading was headed by one Manchu and one Han Chinese high-ranking official, an administrative and supervising staff of 26 , and 32 unranked scribes, secretaries, and assistants. No artisans worked here. The proofreaders were chosen from the members of the Hanlin Academy and were responsible for drafting and editing the more ceremonial government pronouncements or historiographical projects, or from students (gongsheng) of the Imperial University (Guozijian) ${ }^{77}$. Although working at the Wuying dian was prestigious, the ranks of its officers were not high. Most of the intermediate and subordinate positions were not ranked but filled with clerks (baitang'a) or banner people without permanent official posts (sula).$^{8}$ The 'Current regulations and precedents of the Imperial

74 Liu Qiang, 'Qing Wuying dian', p. 268.

75 Ibid., loc. cit.

76 Due to a lack of funds, it was incorporated into the Wuying dian printery xiushu chu in 1843 .

Qinding Zongguan Neiwufu xianxing zeli, p. 318.

77 Huidian, chap. 1199, fol. $6 \mathrm{a} / \mathrm{b}$. Academy students were employed for writing out the transcripts between 1738 and 1769 and again after 1780 . A regulation of 1820 provides that writing one hundred chapters should not last longer than a half year, and correcting one thousand characters should be achieved within twenty days.

78 According to Evelyn Rawski, The Last Emperors, pp. 167-168, the Manchu term baitang'a means 'applicable, useful' and refers to 'errand boys, handymen, underlings', a 'catch-all term for unranked clerks in government offices, artisans, and doctors.' Sula were labourers, from the 
Household Department' contain detailed prescriptions of how Wuying dian positions at all higher levels should be filled by promoting personnel of lower positions into the vacancies.79

As a rule, artisan posts were assigned to banner people and referred to as 'inner-clan work service [positions]' (jianei jiangyi) or 'banner artisans' (qijiang). These artisans were unfree bondservants (booi) of the upper three of the Eight Banners (bordered yellow, plain yellow, plain white) that formed the emperor's household servants. ${ }^{80}$ Bond service was arranged hierarchically. At the top, it could include powerful personalities like Cao Yin, the director of the Imperial Silk Weaveries in Nanjing. Emancipation was possible in special cases. Thus, as mentioned above, Jin Jian and his family were freed from the status of bondservants. ${ }^{81}$ The lowest stratum of bond service was that of the 'state slaves' (sinjeku), who were prisoners of war (or their descendants) and ranked far below the booi. ${ }^{82}$ Sinjeku were employed for physical, often agricultural, tasks on the imperial lands but also within the palace. Sinjeku women also worked in the palace and at the imperial mausoleums and palaces in the secondary capital Shengjing. ${ }^{8}$ It is not recorded whether women worked in the palace printery.

In view of the superior quality of the Wuying dian editions, it is usually assumed that only the most skilled and experienced artisans were employed in the Imperial Printery. However, the 'Current regulations and precedents of the Imperial Household Department' mention that artisans from the Office of Palace Construction (yingzao si) were also employed at times when specialists were missing. These may have been skilled in other crafts (in the case in question, the palace printery 'borrowed' ten paper mounting artisans [biaojiang], two painters [huajiang], and sixteen carpenters [mujiang] from the Office of Palace Construction) but were not professional printers or character carvers. The merit of this arrangement for the Wuying dian was doubtless that these

original Manchu meaning 'idle, unemployed'. The term was applied for banner people without regular official positions. These were menial and low-paid but nevertheless sought-after posts. 79 Qinding Zongguan neiwufuxianxing zeli, pp. 308-309, 'Jianshe yuanyi' 建設員役 (Assigning jobs to administrators).

8o Rawski, The Last Emperors, p. 167. Banners were the basic Manchu military and social organization, but not all banner people were Manchus. Mongols, Koreans, and Han Chinese who had surrendered in the early seventeenth century before the Manchus took over imperial rule were also represented.

81 Eminent Chinese of the Ch'ing Period, p. 159.

82 Rawski, The Last Emperors, p. 171.

83 Ibid., p. 172, mentions more than five thousand sinjeku women in the palace in addition to more than four thousand at the imperial mausoleums in the late seventeenth and eighteenth centuries. 
artisans remained on the payrolls of the Office of Palace Construction. ${ }^{84}$ On the whole, although exterior artisans could be hired, it was obviously preferred to first provide whatever workforce was needed from within the palace personnel. At one point in 1811, Wuying dian artisans numbered 104 banner artisans and only eight [exterior] 'hired artisans' (zhaomujiang) ${ }^{85}$

The 'hired artisans' normally came from the capital, the adjacent districts, or the provinces of Shanxi and Jiangnan. ${ }^{86}$ We do not know whether the six colleagues from the Liuli chang printery Zhuanyun zhai remained in the palace overnight, but at least the artisans from outside Peking probably lived in dormitories on the precincts. The respective regulations of the Imperial Household Department foresaw:

In case of large work projects within the palace, when exterior civilian artisans must be employed, the ministers shall plan to let the overseers of works employ trustworthy foremen, and for this special task, these foremen shall search for calm and law-abiding workers among the artisans with whom they usually come into contact. In addition to overseers of works or of renovations, officials shall be assigned to wait for the artisans at the palaces gates and distribute belt marks ${ }^{87}$ with their names written on them. First the respective overseers of works or overseers of renovations shall examine them outside; then the special delegates shall count and control them on the palace precincts. Every group of ten artisans shall be escorted by one delegate. ${ }^{88}$

When working within the palace, we know that an excellent level of performance was expected from the character carvers, the type setters for the movable type projects, the printers, and the binders. If artisans made too many mistakes, especially with carving or type setting, they could be fined part of or even all of their wages. ${ }^{89}$ For all printing editions and projects, but

84 Qinding Zongguan neiwufuxianxing zeli, p. 309, 'Tiaoqu jiangyi' 挑取匠役 (Selecting artisans' work obligations).

85 Qinding Zongguan neiwufuxianxing zeli, p. 309.

86 Liu Qiang, 'Qing Wuying dian', p. 271.

87 The documents of the Wuying dian in the First Historical Archives contains a 'List of all belt marks given out at the Wuying dian' Wuying dian fa fang gejian yaopai zhang 武英殿發 放個件腰牌賬. Neiwufu ... boce, no. 432-5-41, booklet 02, dated 1905. The belt marks evidently were given out for identification and control of external personnel.

88 Qinding Zongguanv neiwufuxianxing zeli, Guangchusi, chap. 3, p. 57-58, quoted in Peng Zeyi, Zhongguo jindai shougongye, vol. 1, p. 156.

89 Liu Qiang, 'Qing Wuying dian', p. 269, quoting from Huidian, chap. 1050, Hanlin yuan zhizhang - zuanxiu shushi 翰林院, 職掌, 纂修書史. 
especially for the emperor's personal writings, utmost care was required for all parts of the procedures, not least for the proofreading. As a rule, imperial manuscripts had to be proofread three times by officers of increasingly higher status before the transcript for carving could be written out. ${ }^{\circ}$

Few new printing projects were launched in the nineteenth century, and funds for the imperial printeries decreased. Liu Qiang argues that the Wuying dian started to save on expenses for external artisans from Jiangnan and hired Shanxi character carvers instead, who produced lower-quality blocks. Moreover, the qualified banner artisans in permanent positions had become old and frail and were not replaced by equally skilled successors, so that the number of those who actually worked at the Wuying dian decreased to twenty to thirty people. ${ }^{91}$ Among the Wuying dian archival documents in the First Historical Archives, one undated file records the names of the artisans in permanent positions and assistants (sula) of the printing and bookbinding section. In a total of 59 names, there were fourteen artisans in leading positions, 28 'artisans on work obligation' (jiangyi), one carpenter, five 'civilians of Wanping district' (Wanping xian min ) ${ }^{92}$, and eleven sula. The banner affiliation (plain yellow, plain white, and bordered yellow) is recorded for all leading positions and all sula. Only four people are expressly named as 'civilians'. Apparently not all of the artisans always showed up for work; for those who did not, the list reports 'did not arrive' (wei dao). ${ }^{93}$

The trend towards outsourcing is obvious also from the fact that even the small group of five character carvers, together with an unknown but probably equally limited number of printers, binders, and bookcase makers for the 1884 Gongzhong xianxing zeli project were hired entirely from outside.

\section{Wages in the Palace Printery}

Comparatively comprehensive information is available for the wage rate of the imperial printery Wuying dian (see Tables 36 to $39,42,43$ ). The Collected Statutes and the regulations and precedents of the Imperial Household Department show that since wages began to be recorded (1705), they were differentiated into wages for the 'internal' banner artisans and the 'external,

90 Liu Qiang, 'Qing Wuying dian', p. 269.

91 Liu Qiang, 'Qing Wuying dian', p. 271.

92 The Wanping and Daxing districts together made up the territory of urban Peking).

93 Neiwufu ... boce, no. 432-5-41, booklet 03, Wuying dian xiushuchu, shuayin zuo 武英殿修書 處,刷印作 (Wuying dian printery, printing and bookbinding section). 
hired' artisans (see Table 36). However, direct comparison is possible only in one case. The regulations of 1705 state that banner artisans who printed 1,000 sheets of paper received 0.1 tael 'food provision money', but the hired artisans, depending on the quality of the paper printed, were paid monetary wages between 0.12 and 0.16 tael. ${ }^{94}$ While it is not strange from an equitable point of view that external, highly qualified artisans should receive higher wages than the palace employees in permanent positions, who enjoyed other, more long-term benefits, it does show that from the beginning of the eighteenth century at the latest, the palace paid civilian, hired artisans well and did not discriminate against the Han Chinese who served the state temporarily. On the contrary, in 1705 the system of offering the banner artisans in the Wuying dian printery 'official food' (guanfan) had already been abolished. The banner artisans from 1705 onward were paid according to predefined workloads in a wage system equal to that of the hired artisans. ${ }^{95}$ Thus, the pre-1705 stage was a system of time wage payment, and in the later phase, efficiency wages were paid to both banner artisans and the external, Han Chinese artisans.

From the wage lists and the jobs for which external artisans' wages were provided, it seems that the external artisans were engaged in carving and writing out transcripts, while the banner artisans were mainly employed for the binding and ornamentation of the book covers. The section for imperial writings (yushu chu), which was responsible for carving and printing texts authored or personally calligraphed by the emperors, paid higher wages than the printery for the other (non-imperial) texts (xiushu chu). Unlike their colleagues from the xiushu chu, the printers, ink makers, paper mounters, and ink carvers from the section for personal writings of the emperors also retained the right to food provisions. These consisted of daily rations of 2 liang mutton (74.6 g), 9 ge old rice (0.93 l), 1 liang sauce (37.3 g), 5 qian light sauce $(18.65 \mathrm{~g}), 4$ liang bean curd $(149,2 \mathrm{~g})$, 2 liang bean sprouts (74.6 g), 1 jin brushwood (596.8 g), and 1 liang charcoal (37.3 g). ${ }^{6}$ After about sixty years, the bean curd and bean sprouts were no longer provided but instead converted to monetary payments given as exactly 0.0032924 tael per daily ration. ${ }^{97}$ For the ranked and unranked officials, these rations were higher, and the provisions in kind were continuously given out in addition to

94 Huidian, chap. 1199, fol. 2 b.

95 Ibid., fol. 2 a.

96 Ibid., fol. 9a/10a. 'Old rice' refers to grain that had been stored at the granaries for several years.

97 Ibid., fol. 11b. It was a custom of the Qianlong era to give accounting data in extremely fine units. 
their salaries. ${ }^{8}$ However, in the section for imperial writings, the multiple controlling and proofreading procedures have to be taken into account, so that it took much longer to finish a block with imperial script and receive the according wages than for other texts.

Comparing the standard workloads to be achieved within one workday (gong), like copying one-hundred characters for a transcript to be pasted in mirror image on the block and subsequently embossed, carving onehundred characters, or printing one-thousand sheets, the nominal wage level expressed in silver tael seems to have remained more or less equal over long time spans. However, if one realizes that these formal wages were converted to copper cash, this has radically different implications. In the mid-eighteenth century, when copper cash was scarce and became expensive, the low exchange rate must have caused discontent, while wage notation in silver was very much to be preferred during the early nineteenth century and especially after the mid-nineteenth century, when copper inflation raised the exchange rate to more than ten times that of the ideal rate of 1:1,000.

The accounts book of the Zhuanyun zhai are in both silver and copper cash for different types of expenses (Table 44). The fees of 0.24 tael for every 100 characters carved, a very considerable rate compared to the earlier wage rates of a maximum of 0.16 tael, are accounted for in silver (Table 46). It is doubtful whether this rate meant that the wages were actually paid out in silver. Presumably the print shop deducted part of the money as a transaction fee and paid it out in copper. However, the food and drink money was accounted in copper cash and probably flowed more directly into the hands of the artisans. Wages for printing and binding were not accounted for but occur only as expenses for the daily food and drink allowances, 400 cash, for seventy workdays. ${ }^{99}$ If one compares the palace wages to those of the provincial printery of Zhili (Table 40), the wages for carving 100 characters -0.044 tael for carving new blocks and 0.065 for adding text to existing blocks - were only one-half of those of the palace. Comparison with the few wage rates that are known for commercial printing (Table 48) indicate that the wages paid by the government were higher than those in commercial printing. Nevertheless, some direct and indirect evidence shows that the inflexibility of the wages paid by the government raised

98 See Liu Qiang, 'Qing Wuying dian', p. 272, for details about the various food rations in the hierarchy of Wuying dian officials. As Liu Qiang points out, after 1845, the meat ration was reduced for leading officials and definitely abolished for the artisans.

99 Neiwufu zeliguan 内務府則例館 23 , Fuwen 附文 (Additional note) 1, and 3, p. 1-2. 
problems when the cost of living increased. The wage raise of 0.01 tael per hundred characters for the externally hired artisans who wrote out the transcript for the yearly calendar Zhongxing genglu between 1751 and 1795 can be understood in this way (Table 41). ${ }^{100}$ In 1810, the Wuying dian printers pleaded for augmentation of their wages because they could no longer make ends meet. Consequently, they received a wage raise of 0.02 tael for every 100 characters carved, and 0.01 tael for every 100 characters of the transcripts copied out. Moreover, if blocks had to be corrected and if these corrections made it necessary to recarve subsequent blocks, the foremen could now account for the costs of the corrections and did not have to deduct these from wages. ${ }^{101}$ Thus, although the artisans employed in the imperial printery may have experienced difficulties in securing their livelihood, some indications show that at least until the mid-nineteenth century, the authorities tried to comply with their requests. One example may show that these artisans were comparatively well taken care of. In the winter and summer months, temperatures in the palace workshops were always a problem. For instance, the palace studio of the Jesuit painter Denis Attiret (1702-1768), who worked for the Qianlong emperor between 1739 and 1768 , was heated only by a small furnace in winter for keeping the paint from freezing, and in summer became stiflingly hot because it was unsheltered from the torrid sunshine. ${ }^{102}$ Apparently, the working conditions in the Wuying dian were somewhat better. Not only were stoves and fuel provided in the winter months but in the summer matting was provided to shade the workplaces and ice blocks were applied to lower the temperature. While heating in winter was used commonly in Peking, cooling in summer was rather exceptional, at least for commercial printers. ${ }^{103}$

\section{Working and Living Conditions of Commercial Printers}

Book historians have pointed out that more names of late Ming printers are known from imprints in books than of their successors in the early and mid-Qing, probably due to the fear of the consequences of the literary

100 Huidian, chap. 1199, fol. 11b/12a. Actually, the wages had been reduced by 0.01 tael in $175^{1}$ and were raised again to the pre-1751 level in 1795 .

101 Zhang Xiumin, Zhongguo yinshua shi, p. 756, quoting from the accounts of the imperial printery at the Wuying dian, Wuying dian xiushuchu baoxiao dang'an 武英殿修書處報銷檔 案.

102 Veit, 'Jean-Denis Attiret', p. 144.

103 Zhang Xiumin, Zhongguo yinshua shi, p. 756. 
inquisition. ${ }^{104}$ This fear receded gradually in the nineteenth century, and thus more is known about character carvers, printers, and book binders from this era. Amazingly enough, the character carvers were often illiterate. ${ }^{105}$ Little capital was available and necessary for commercial printing, and in order to remain competitive, one option for publishers was to outsource the most cost-intensive job of character carving to rural regions, even if the carved blocks had to be transported over long distances. Suzhou publishers, for instance, had their blocks carved in Magang in Guangdong province, which lies at a distance of more than one thousand kilometres from Suzhou.

Character carving was a craft branch in which many women and girls were engaged. This is well attested for Magang in Guangdong and Xuwan in Jiangxi. Magang and Xuwan brides often received their self-carved blocks as their dowries. ${ }^{106}$ In the block-printing region Yongzhou in Hunan province, girls and boys of young age would 'carve the blocks while leaning on a tree and tending the oxen'. ${ }^{107}$ The employment of young and female labour explains the low wages paid and thus the competitiveness of these rural locations (see Table 48). However, the quality of their work is generally assessed as low. It was executed swiftly and contained many errors. The adult women would usually work in their own houses; 'in exceptional cases', the elderly women would also manage the household subsidiary business, especially when men were sojourning elsewhere. ${ }^{108}$

Cynthia Brokaw, to whom we owe so much firsthand information on the practice of traditional printing, has illustrated several business forms and patterns of labour recruitment. ${ }^{109}$ Yuechi in Sichuan province was a rural setting where carving was predominant and only very little publishing was practised. For the most part, it supplied the publishing houses in the metropolises of Chongqing and Chengdu, which were at distances of over 100 and 200 kilometres respectively. Work was either sent out or the carvers, who were all male, sojourned and were permanently engaged at the Chengdu or Chongqing publisher/booksellers' enterprises.

104 Ibid., p. 754.

105 Brokaw, Commerce in Culture, p. 14, McDermott, Social History of the Chinese Book, p. 35. McDermott also specifies on pp. 29-3o that the carving process was divided in a way that all similar strokes (horizontal, vertical, slanting) of all characters on a block were carved separately, which made division of labour and consecutive work of several people possible.

106 Zhang Xiumin, Zhongguo yinshua shi, p. 754; Brokaw, Commerce in Culture, p. 540.

107 Zhang Xiumin, Zhongguo yinshua shi, p. 754.

108 Brokaw, Commerce in Culture, p. 133.

109 Ibid., pp. 537-546. 
Xuwan in Jiangxi was much better connected by water and land to the greater cities on the middle and lower Yangzi. It was a publishing and printing centre where the male and female labour force was recruited from the surrounding villages. The carvers, printers, and binders either worked at the publishers' shops, or the blocks were delivered to them for carving.

Mainly women were engaged in Magang in Guangdong. They supplied the publishers in nearby Foshan and Canton. A few of the women were specialists, but for most, carving was subsidiary business that was outsourced to them by the shop managers of the printing shops. No female sojourners came from Magang, since women as a rule did not work outside of their own families before the twentieth century. However, male sojourning was common in Shunde prefecture, where the district Magang is situated. Shunde is well known to sociologists for the habit of female 'marriage resistance', which means that parents were willing to let their daughters stay at home after marriage or live together with other women. ${ }^{110}$ The women who did not join their husband's household were most often engaged in silk reeling and worked outside their homes in silk filatures; no cases of character carvers are reported. Nevertheless, it may not be pure chance that the trade was practised here, where greater female independence caused by wage earning outside family abodes created the rare equivalent of the non-religious sorority. ${ }^{111}$

In the rural Sibao region in Western Fujian, some of the fifty and more publishing houses also bought the printing blocks from elsewhere, for instance from the Magang women carvers. ${ }^{112}$ Actually, the Sibao publishers used various forms of labour supply to produce the books they distributed in the entire southern part of China. In interviews with the members of publisher lineages, informants said that writing the transcript and carving characters was highly skilled labour that was done by the elders of the households. Other character carvers travelled to their customers and were offered free board and accommodation in the publisher's family or at a local temple while working on a particular project. ${ }^{113}$ Since the equipment needed by the itinerant carvers and printers - knives and brushes - was light and unsophisticated, this was a logical option for low-capital publishing.

110 See Hill Gates, China's Motor, pp. 189-191, who refers to the relevant studies by Marjorie Topley (1975), Janice Stockard (1989), and Andrea Sankar (1978).

111 Professional sororities like 'self-combing women' were not confined to Shunde but occurred in all of Guangdong and Guangxi. Their members worked mainly in the silk industry. Jinsheng, 'Yue Gui de 'zishu nü', p. 89.

112 Brokaw, Commerce in Culture, p. 101.

113 Ibid., pp. 96-98, 99. 
This was even more so if the books to be produced were not required in large print runs. A typical job for itinerant printers was the production of genealogies, which they could conveniently carve and print at the ancestor shrines of rural well-to-do lineages. ${ }^{114}$ The migrants often exercised their trade as a subsidiary business in the agricultural slack season and as a rule had not received any formal training. In contrast, an apprenticeship system existed for professional character carvers that lasted from three to five years, starting at age nine or ten. ${ }^{115}$ In Yuechi and Magang, the children were also first taught the skills of carving at age nine or ten for one to three years before they were given paid work. ${ }^{116}$

Printing and binding could be done as unpaid family work by women or children. One of the two big publisher families in Sibao, the Zous, had a 'book printing school' (yinshu xuetang) in one of their ancestral halls by the mid-eighteenth century, which might have been a place to train character carvers, printers, and binders in the family business. ${ }^{117}$ In Sibao, the printing and binding of books were usually done by women, sometimes with the help of children, in their own homes. ${ }^{118}$ In less rural settings - for example, the market town of Xuwan in Jiangxi - printing was usually done in the back rooms of the publishing and bookselling houses. ${ }^{119}$

Since the largest proportion of Sibao's production was school books, most of the production had to be ready by the beginning of the school year after the Chinese New Year in January or February. In the 1920 s and 1930s, a smaller shop specializing in schoolbooks would at New Year's day need a stock of 2,000 to 3,000 copies of the reading and writing textbook Sanzi jing ${ }^{120}$ and 800 to 1,000 other primers and textbooks. With a labour force of household members and two hired female labourers, a publishing house could print and bind 100 copies of the Sanzijing in one day. For a sum of 4,000 primers, at least 40 workdays would be necessary to finish this target. ${ }^{121}$

1930s wages in Sibao ranged from 0.2 and 0.4 to 0.5 yuan for every 1,000 sheets printed, and thus about 0.6 yuan to 1.2-1.5 yuan per day with an

114 Zhang Xiumin, Zhongguo yinshua shi, p. 757.

115 Brokaw, Commerce in Culture, p. 14, for professional character carvers from Yuechi in Sichuan. 116 Ibid., p. 540, 545 .

117 Brokaw, Commerce in Culture, p. 105, referring to a 1947 lineage genealogy of the Zou family, Fanyang Zoushi zupu.

118 See ibid., p. 106, fig. 3.3 for a photograph of such printing rooms, and her detailed description of the printing process, pp. 107-111.

119 Ibid., pp. 105-106, fn. 64.

120 This is a short text with 1,128 characters. In its original form, it would fit on three printing blocks of four hundred characters each, but can be extended by commentaries of various lengths. 121 Brokaw, Commerce in Culture, pp. 122-123. 
average daily print run of about 3,000. ${ }^{122}$ In comparison, the wages reported for the Qingdao handicraft printers were anywhere between eight and 15 yuan per month, with an average of ten yuan (see Table 34). If the Qingdao printers worked for 25 days, their daily wages would vary between 0.6 and 0.32 yuan, with an average of 0.4 yuan. Thus, in the high season, Sibao wages would surpass those of Qingdao, but daily production was not always as high as 3,00o pages throughout the year and may have been more evenly spread in the city of Qingdao.

In China's centre of modernity and capitalist production, Shanghai, the mechanized printing industry emerged in the last decades of the nineteenth century. Lithography thrived from the 1870 s and was surpassed by the letterpress only in the early twentieth century. But block printing had not yet completely disappeared in Shanghai. By the 189os, it was still used in a missionary textbook edition started in 1879 , although the missionary publishers had first introduced printing machinery to China. ${ }^{123}$

While the scope of block printing compared to letterpress and lithography has yet to be explored, the relation of the letterpress and lithography is better researched. Christopher Reed estimates that the number of workers in all Chinese lithographic printeries may have been as high as 8,050 by 1894 as against only 870 letterpress workers. He also mentions that between 1876 and 1911, 149 lithographic printers started business in Shanghai, relative to only 21 lead type shops between 1842 and $1911 .{ }^{124}$ In Reed's view, the decline of lithography and the rise of the letterpress can be attributed to the fact that although lithographic printing could produce less expensive books than block printing, in relation to the letterpress the necessary workforce was still too large. The use of kerosene and steam power could reduce the number of workers per machine from eight to three, but the lithographic workshops still employed 100 to 200 workers each because preparing the stone plates, copying the text, and reducing its size by photography required a much larger workforce than letterpress printing. By the 1920s, although the wages reported for lithographic copyists were astonishingly low ( 0.3 yuan to 0.1 yuan per thousand written characters), ${ }^{125}$ contemporary Chinese and foreign observers found that, in view of the cost performance, the alternative technology of letterpress printing was preferable.

122 Ibid., p. 131.

123 Reed, Gutenberg, p. 320, fn. 32, quoting John Fryer, Records of the General Conference of the Protestant Missionaries of China, p. 715 .

124 Ibid., p. 97, 121.

125 Ibid., p. 322, fn. 54, quoting from Chen Cunren, Yinyuan shidai shenghuo shi (Everyday life history of a dark age), p. 232. 


\section{The Social Status of Publishers and Printers}

Carvers, printers, and binders produced indispensable receptacles of scholarly knowledge, but their crafts were not considered to be highly qualified occupations. This may have to do with the simplicity of the production process. Neither complicated devices (like weaving looms) nor risky installations (such as a furnace or kiln) were necessary. Printing with movable type was not unknown but still relatively uncommon. Therefore, we do not know whether the image of the typesetters was any higher than that of the character carvers. Compared to building or shipbuilding, printing did not require much capital: a relatively small, often female or young household-based labour force could accomplish its projects. In rural settings, writing out the transcript was therefore done by family elders and managers with some knowledge of characters and was considered the highest qualified part of printing. In the palace printery, where we can assume a higher literacy rate, the carving of characters earned twice the wages of copying, as it took much longer to carve a character than to write it with a brush (see Table 36 ). However, the best paid tasks were proofreading and control of work processes rather than copying the transcript or carving characters. The printers and binders earned the lowest wages.

In the family publishing business, where printing was often a subsidiary occupation during the agricultural slack season, a gender and age division prevailed in which women and children produced the books and men decided which books to print. It was also the men who distributed and sold the books after they were produced. ${ }^{126}$

There is ample proof in the field of printing of one of the assumptions of this study, namely that the status of artisans and commoners within the 'four occupational groups' was actually reversed in the sense that not merchants but artisans ranged last. Among the merchants, the publisherbooksellers were held in comparatively high esteem, especially when they managed to create the image of printing not for profit but to generously spread information to all those who needed it.

Once again, Cynthia Brokaw provides insights into how the Sibao book traders were perceived by the local elite of society. Even if they were commended for earning their living by 'plowing the Classics and sowing the historiographies' (geng jing jia shi)' or for their competence in character carving, ${ }^{127}$, praise of such a condescending nature demonstrates the low status of book merchants, even if they were trading in Confucian items. 
Attitudes did change when the artisans and the elite scholar-officials came into direct contact. For one, if asked to write stele texts for guild houses, the scholar-officials would certainly do so. Thus, the author and the calligrapher of the 1898 stele inscription and the character designer of the inscription board of the character carvers' guild temple Wenchang miao in Peking were both Hanlin academicians and compilers of the Collected Statutes; the author, Yang Shixiang (1860-1909), served as Governor-General of Zhili province between 1907 and 1909. On behalf of the character carvers who feared a crisis in traditional learning and official examinations, he expressed the hope that Confucian writing and character carving would persist and secure the living of those in the association. ${ }^{128}$

More precise are the few examples of acknowledgement to the book carvers' efforts documented in Zhang Xiumin's book history. In the light of the files of the Wuying dian in the First Historical Archives, Zhang's complaint that virtually no printers' names from the Qing are transmitted (as against seventy to eighty from the Ming) seems no longer tenable, but much more research in local archives will be necessary to explore the characteristics of all Chinese printing centres. Even then, it will be difficult to find more names of female printers. According to Zhang Xiumin, precisely one female character carver, who lived in Songjiang in Jiangnan province during the Qianlong reign, is known by her family name Ma because the customer whose poetry collection she carved thanked her in a poem. ${ }^{129}$ Among the few known male carvers is Liu Yongri, a master from Suzhou who in 1671 was honoured by a literatus whose poems he carved in extraordinarily elegant characters, with a 'Preface for the character carver Liu Yongri's sixtieth birthday'. The text praises Liu's reliability, stating that although he was sixty, he walked every day, rain or shine, to his customer's house to fulfil his task. ${ }^{130}$

Another master who rose above anonymity was Zhu Gui from Suzhou. Coming from an impoverished scholar family, Zhu in the Kangxi reign 'changed his trade' and started to carve texts and illustrations. His most famous works are 'Charts of plowing and weaving' (Gengzhitu) that had been commissioned by the Kangxi emperor and the pageant on the 'Emperor's birthday celebrations' (Wanshou shengdian). Having ingratiated himself to

128 Li Hua, Ming Qing yilai, pp. 162-163, 'Chongjian Wenchang ci ji’ 重建文昌祠記 (Record of the renovation of the Wenchang shrine).

129 Zhang Xiumin, Zhongguo yinshua shi, p. 755, who quotes the verse from this poem 'with profuse efforts, a female worker carved my worthless writings in pear wood' 漫勞紅女為灾梨 which is explicit about the gender of the carver.

130 Zhang Xiumin, Zhongguo yinshua shi, p. 758, 'Jijue shi Liu Yongri liushi shou xu' 㢦劂氏劉 永日六十壽序 (Preface for character carver Liu Yongri's sixtieth birthday). 
the court, he managed to secure a low-echelon official position in the Court of State Ceremonials (Honglu si) of the Imperial Household Department. ${ }^{131} \mathrm{He} \mathrm{had}$ risen to officialdom not exclusively due to his artisan skills but also because of his family's scholarly status. What certainly helped him to promotion was that he also carved illustrations and that his work was thus associated with art. This was also the case with the block printer's family of Huang Lizhong (1652-1738) from Qiu village in the She district in Huizhou prefecture, who was already in the trade during the Ming dynasty and rose to local fame because of the family's charitable activities. ${ }^{122}$ In the Ming period, the Huang family did not try to disguise their origins as artisans and merchants but actively sought - like other artisans, especially potters, gardeners, bamboo carvers, and lacquerers who produced art and craft items - to acquire a literati image. They practised and refined their skills in calligraphy, painting, music, and poetry and also participated in civil examinations but never ascended above the local level. Their gains from commercial activities enabled this family of 'literati carvers' to attain prominence. ${ }^{133} \mathrm{~A}$ further case is that of $\mathrm{Mu}$ Jinwen (1721-1812) from Suzhou, a 'plain-clothed' (buyi) scholar without office and famous character carver who combined the scholarly, art connoisseur, merchant, and philanthropic levels of the trade or art and thus remained at the social level of the literati, with famous friends such as the men of letters Yuan Mei (1716-1797) and Qian Daxin (1728-1804).

Intermediary stages between the artisan and the artist existed as well and have been aptly described by James Flath. New Year's posters usually come with colophons. As a rule, the master artisan designers of the popular block prints in rural North China had not received systematic Confucian schooling and therefore were not completely proficient in the literary style but nevertheless tried to avoid the vernacular for their illustrations, thereby creating in their prints a half-popular and half-literary style. Only in a few cases did accomplished artisans design New Year's posters, such as the painter Qian Hui'an (1833-1911) from Shanghai or the designer Gao Tongxuan (1835-1906), both of whom worked at Yangliuqing. From Gao Tongxuan's workshop, we also know how the hierarchy of master and subordinate artisans who processed his drafts translated into remuneration. One draft by Gao Tongxuan earned about five to six yuan, and with an average of 170 designs per year, his income was about ten times that of the artisans in his print shop. ${ }^{134}$

131 Zhang Xiumin, Zhongguo yinshua shi, p. $75^{8 .}$

132 Ibid.

133 McDermott, Social History of the Chinese Book, pp. 35-36.

134 Flath, Cult of Happiness, p. 16. 


\section{Conclusion}

To assess the role of the Qing state in the private printing sector, book historians point out that previous dynasties preferred to reserve the books of the palace printeries for court and government use, so that private printers had no chance to obtain and use them as exemplars for reprints. ${ }^{135}$ Yet in the Qing dynasty, most of the printed products of the Wuying dian were sold to those who could afford the prices, which were already high in the eighteenth century. This change may be attributed to the greater anxiety of the first Manchu rulers to present themselves as active guardians and promoters of the Han Chinese civilization, moral philosophy, and book learning. However, the outsourcing of the re-edition of the imperial encyclopedia Gujin tushu jicheng stands in strong contrast to the imperial vigour and activism of the early eighteenth century. It also shows the degree to which the enhanced productivity of lithography and letterpress enabled the Shanghai and Canton elites to promote the cultural aspect of the self-strengthening project - who were still in the service of the dynasty and the court, notwithstanding their latent anti-Qing feelings.

In the seventeenth and eighteenth centuries, the court and central government controlled the contents of the printed matter issued by private publishers to the extent that actual and supposed anti-dynastic writings were not tolerated at all. Since the waves of inquisition came sporadically but unexpectedly, publishers and printers were generally careful not to criticize the government. However, no restrictions for politically neutral contents applied. Investments for lithography or letterpress and typecasting devices were neither hindered nor encouraged by the state. The organization of Chinese handicraft printing and the transition to mechanized printing was left to the printers, especially in the treaty ports which were within the jurisdiction of foreign powers.

Journals were forbidden time and again, for instance when the constitutional Hundred Day Reforms were crushed in $1898 .{ }^{136}$ However, the Shanghai-based journals remained out of the reach of the central government due to the extraterritorial status of that city. In 1906, the first press and publication law (Da Qing yinshuawu zhuanlü) was promulgated, and the newly established Ministries of Commerce, Education, and Surveillance jointly supervised a 'General Printing Bureau' (Yinshua zongju) where all printeries and newspapers had to register. ${ }^{137}$ 
Previous Chinese craft historians have claimed that the state exploited the artisans recruited from the private sector. ${ }^{138}$ However, looking at the palace printery Wuying dian, we find that as far as wage payment is concerned, this was certainly not the case. Wages in the palace tended to be higher than in the Peking private sector, and the treatment of the artisans that were engaged in all parts of the printing process was considerate in terms of food provisions, heating, and cooling, as far as we can tell from various sources. Work in the palace was highly hierarchic, and the banner affiliation played a great role. If the banner craftspeople were not free to leave their permanent positions at will, this can be understood as exploitative. However, this did not concern the hired civilian artisans.

In the non-government sector, the position of artisans was to a large extent subordinated to the merchant publishers in the trade, so that, as in other craft occupations, the path to social success and prestige went predominantly through commerce. There were hardly any character carvers and no printers or binders who could achieve fame only by their craft skills. In this branch of cultural production, the advancement in status from artisan to artist was possible, but this held more for those who designed illustrations than for those who only carved characters. As for the women in the trade, who are more visible here than in other crafts, the chance to manage a print shop may have arisen when the men in the family were missing or sojourning elsewhere. However, most of them practised the craft as unpaid family work or as a subsidiary business to their agricultural labour.

At the end of the dynasty, printing activities were to be found in extremely different locations. In the modernizing cities, an increasing number of book and newspaper publishers operated mechanized presses, although even here, block printing persisted for some time. Particularly in the rural regions, where raw materials were easily available, wood blocks for elementary schoolbooks were still carved by hand. In the hinterland, as education was spread through government reforms and private initiative, the commercial and the subsistence sectors came into much closer contact than when the Manchus conquered the Ming empire.

138 Zhu Cishou, Zhongguo gudai gongye shi, 'The ebb and rise of the official and private crafts', p. 787, 795; Tong Shuye, Zhongguo shougongye shangye fazhan shi, p. 316. 


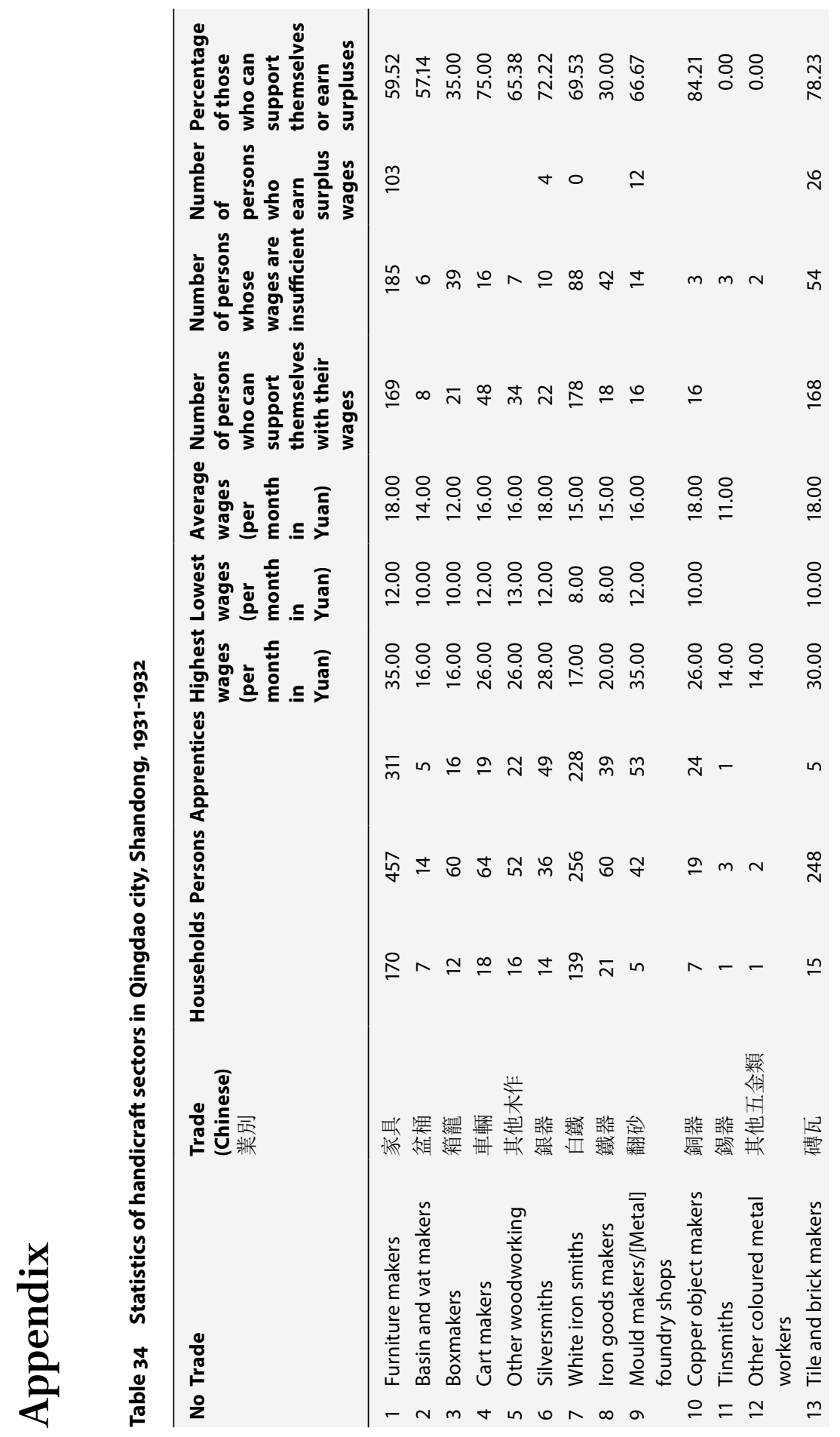




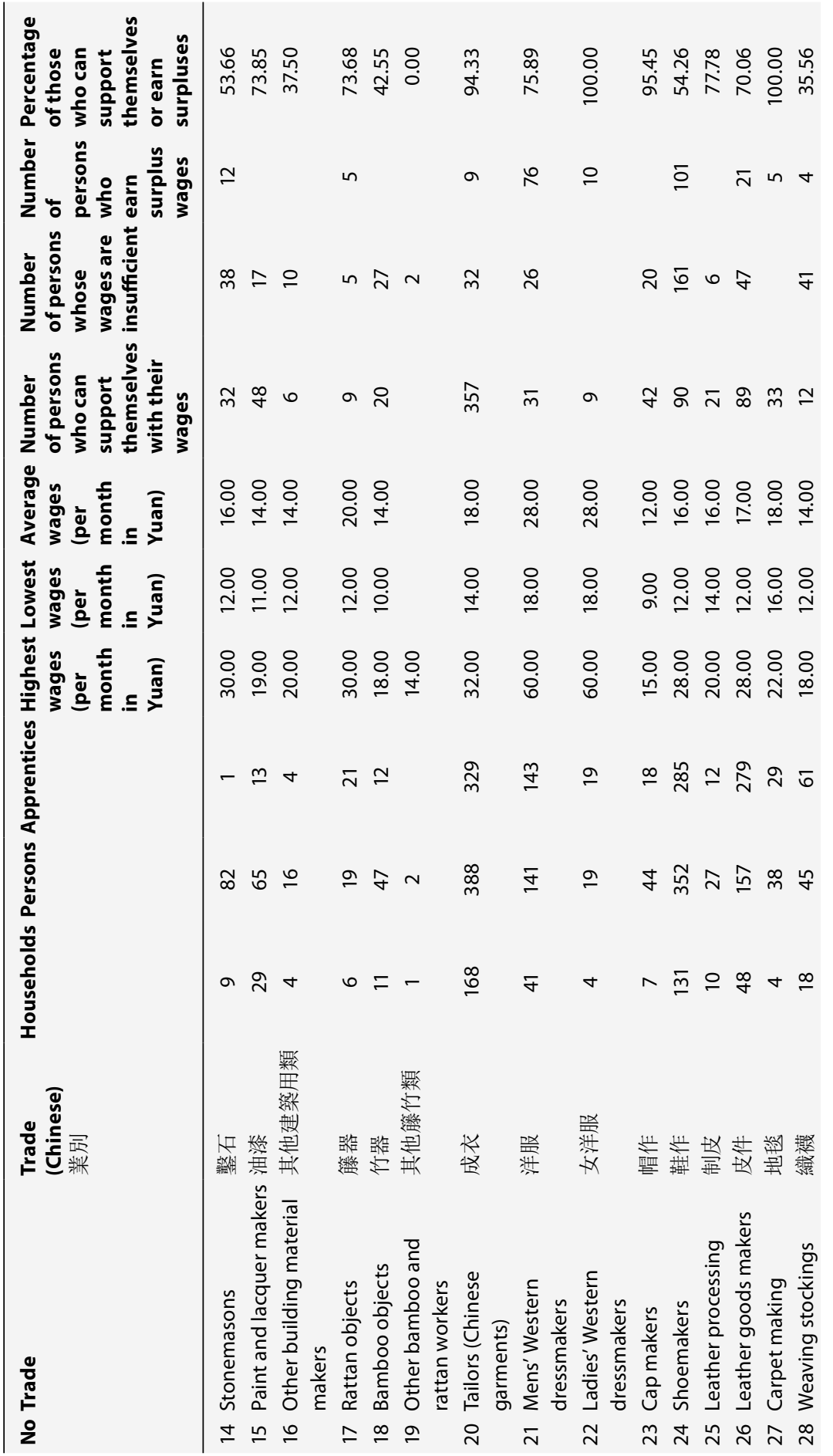




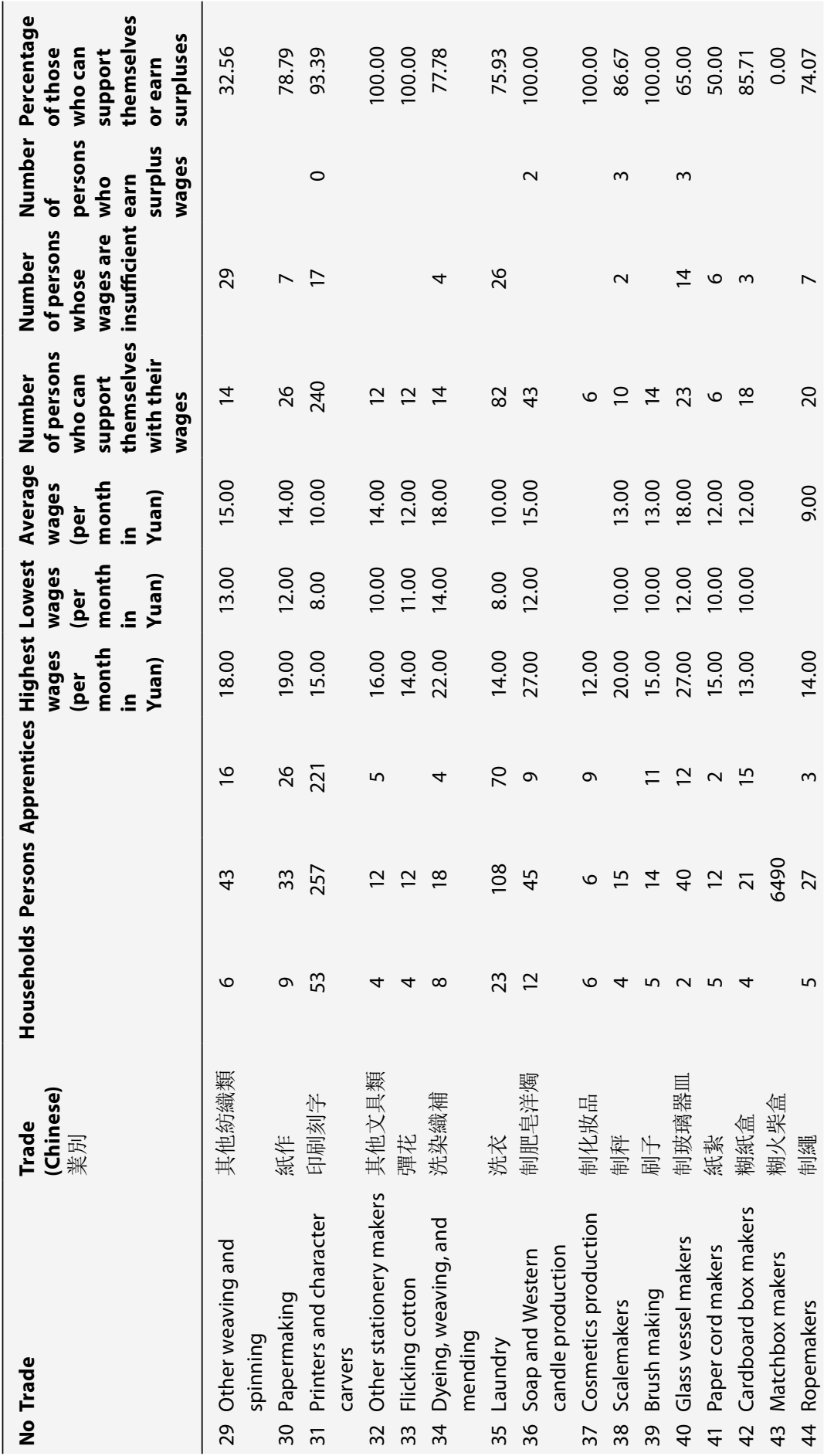




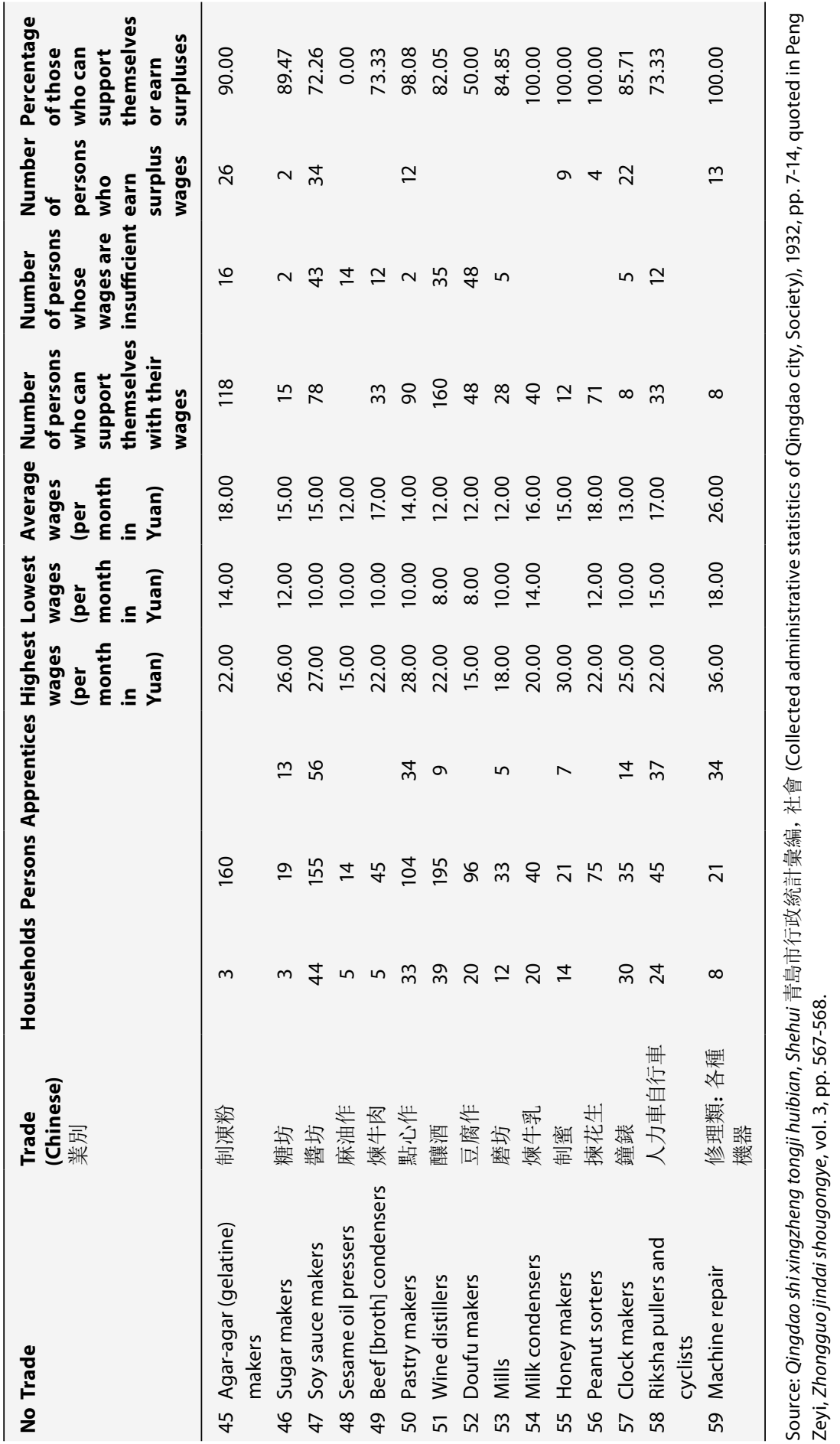




\section{Table 35 Position of handicraft printing and character carving among all craft trades in Qingdao, 1931-32}

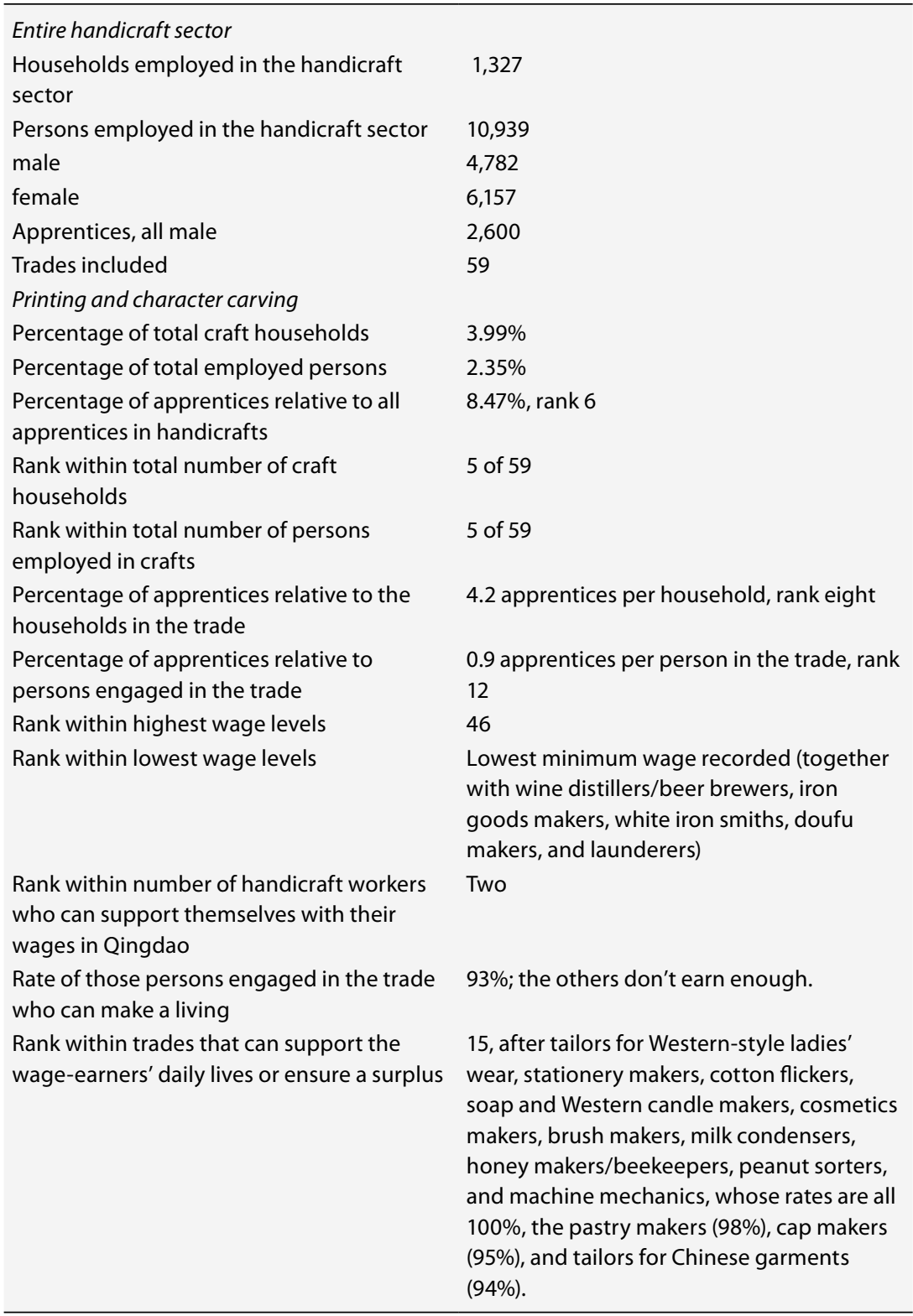

Source: See Table 34. 
Table 36 Government wage rates for block printing and binding, 1705

\begin{tabular}{|c|c|c|c|c|}
\hline Status group & Work procedure & $\begin{array}{l}\text { Work procedure } \\
\text { in Chinese }\end{array}$ & Unit & $\begin{array}{l}\text { Wage in silver } \\
\text { tael }\end{array}$ \\
\hline $\begin{array}{l}\text { Banner artisan } \\
\text { printer家內匠役 }\end{array}$ & Printing & 刷書 & $\begin{array}{l}1,000 \\
\text { sheets }\end{array}$ & $\begin{array}{l}0.1 \text { food provision } \\
\text { money }\end{array}$ \\
\hline $\begin{array}{l}\text { Banner artisan } \\
\text { book binder }\end{array}$ & Making book covers & 作書 & One & $\begin{array}{l}0.1 \text { food provision } \\
\text { money }\end{array}$ \\
\hline $\begin{array}{l}\text { Banner artisan } \\
\text { border designer }\end{array}$ & $\begin{array}{l}\text { Drawing lines and } \\
\text { columns }\end{array}$ & 畫界 & $\begin{array}{l}160 \\
\text { sheets }\end{array}$ & $\begin{array}{l}0.1 \text { food provision } \\
\text { money }\end{array}$ \\
\hline $\begin{array}{l}\text { Banner artisan } \\
\text { book binder }\end{array}$ & $\begin{array}{l}\text { Making small book } \\
\text { covers }\end{array}$ & 做小套 & One & $\begin{array}{l}0.05 \text { food provi- } \\
\text { sion money }\end{array}$ \\
\hline $\begin{array}{l}\text { External, hired } \\
\text { artisan外雇匠役 }\end{array}$ & $\begin{array}{l}\text { Tracing the } \\
\text { emperor's } \\
\text { handwriting }\end{array}$ & 鉤摹御筆發刻 & $\begin{array}{l}\text { Each } \\
\text { character }\end{array}$ & 0.01 money wage \\
\hline $\begin{array}{l}\text { External, hired } \\
\text { artisan }\end{array}$ & $\begin{array}{l}\text { Carving letters for } \\
\text { inscription boards } \\
\text { or the throne }\end{array}$ & 刊刻圍屏板墻寶座 & & $\begin{array}{l}\text { wage according } \\
\text { to size }\end{array}$ \\
\hline $\begin{array}{l}\text { External, hired } \\
\text { artisan }\end{array}$ & $\begin{array}{l}\text { Carving printing } \\
\text { style characters } \\
\text { (Song type), for } \\
\text { block printing }\end{array}$ & 刻宋字 & $\begin{array}{l}100 \\
\text { characters }\end{array}$ & 0.08 \\
\hline $\begin{array}{l}\text { External, hired } \\
\text { artisan }\end{array}$ & $\begin{array}{l}\text { Carving handwrit- } \\
\text { ing ('soft') style } \\
\text { characters }\end{array}$ & 刻輢字 & $\begin{array}{l}100 \\
\text { characters }\end{array}$ & 0.14 to 0.16 \\
\hline $\begin{array}{l}\text { External, hired } \\
\text { artisan }\end{array}$ & $\begin{array}{l}\text { Copying printing } \\
\text { ('Song') style } \\
\text { characters for the } \\
\text { transcript }\end{array}$ & 寫宋字版樣 & $\begin{array}{l}100 \\
\text { characters }\end{array}$ & $0.02-0.04$ \\
\hline $\begin{array}{l}\text { External, hired } \\
\text { artisan }\end{array}$ & $\begin{array}{l}\text { Copying handwrit- } \\
\text { ing ('soft') style } \\
\text { characters }\end{array}$ & 寫輀字 & $\begin{array}{l}100 \\
\text { characters }\end{array}$ & 0.04 \\
\hline $\begin{array}{l}\text { External, hired } \\
\text { artisan }\end{array}$ & $\begin{array}{l}\text { Folding and fixing } \\
\text { the sheets }\end{array}$ & 摺配齊訂書籍 & $\begin{array}{l}1,000 \\
\text { sheet }\end{array}$ & 0.13 \\
\hline $\begin{array}{l}\text { External, hired } \\
\text { artisan }\end{array}$ & $\begin{array}{l}\text { Printing on fourfold } \\
\text { Lianzhou paper }\end{array}$ & 印刷連四紙書 & $\begin{array}{l}1,000 \\
\text { sheet }\end{array}$ & 0.16 \\
\hline $\begin{array}{l}\text { External, hired } \\
\text { artisan }\end{array}$ & $\begin{array}{l}\text { Printing on bamboo } \\
\text { paper }\end{array}$ & 印刷竹紙書 & $\begin{array}{l}1,000 \\
\text { sheet }\end{array}$ & 0.12 \\
\hline $\begin{array}{l}\text { External, hired } \\
\text { artisan }\end{array}$ & Cutting pages & 裁書 & $\begin{array}{l}1,000 \\
\text { sheet }\end{array}$ & 0.02 \\
\hline
\end{tabular}

Source: Huidian, chap. 1199, fol. 2a-3a. 
Table 37 Government wage rates for the production and setting of copper characters for the Imperial Encyclopedia Gujin tushu jicheng, 1726 and 1728

\begin{tabular}{lll}
\hline Work procedure & Work unit & Wage \\
\hline Copper type setting & & 3.5 tael per month food provision money \\
Carving movable copper types & Each type & 0.025 tael money wage \\
\hline
\end{tabular}

Source: Huidian, chap. 1199, fol. 1a.

Table 38 Government wage rates for block printing, binding, and ornamentation of books and covers at the printeries for the emperor's personal writings, yushu chu, 1768

\begin{tabular}{|c|c|c|c|c|c|}
\hline Status group & $\begin{array}{l}\text { Work } \\
\text { procedure }\end{array}$ & $\begin{array}{l}\text { Work } \\
\text { procedure } \\
\text { in Chinese }\end{array}$ & $\begin{array}{l}\text { Size of } \\
\text { carved } \\
\text { characters }\end{array}$ & $\begin{array}{l}\text { Quantity } \\
\text { per } \\
\text { workload } \\
\text { (gong) }\end{array}$ & $\begin{array}{l}\text { Wage } \\
\text { for every } \\
\text { workload in } \\
\text { silver tael }\end{array}$ \\
\hline $\begin{array}{l}\text { External, hired } \\
\text { character carver ( } \\
\text { 外雇刻字人) }\end{array}$ & $\begin{array}{l}\text { Carving } \\
\text { characters }\end{array}$ & 刻字 & $0.32-3.2 \mathrm{~cm}$ & 10 & 0.24 \\
\hline $\begin{array}{l}\text { External, hired } \\
\text { character carver }\end{array}$ & $\begin{array}{l}\text { Tracing } \\
\text { characters in } \\
\text { black or red }\end{array}$ & 鉤墨頂硃 & & 60 & 0.24 \\
\hline $\begin{array}{l}\text { External, hired } \\
\text { character carver }\end{array}$ & $\begin{array}{l}\text { Carving } \\
\text { characters }\end{array}$ & 刻字 & $3.52-6.4 \mathrm{~cm}$ & 8 & 0.24 \\
\hline $\begin{array}{l}\text { External, hired } \\
\text { character carver }\end{array}$ & $\begin{array}{l}\text { Tracing } \\
\text { characters in } \\
\text { black or red }\end{array}$ & 鉤墨頂硃 & & 48 & 0.24 \\
\hline $\begin{array}{l}\text { External, hired } \\
\text { character carver }\end{array}$ & $\begin{array}{l}\text { Carving } \\
\text { characters }\end{array}$ & 刻字 & $6.72-9.6 \mathrm{~cm}$ & 4 & 0.24 \\
\hline $\begin{array}{l}\text { External, hired } \\
\text { character carver }\end{array}$ & $\begin{array}{l}\text { Tracing } \\
\text { characters in } \\
\text { black or red }\end{array}$ & 鉤墨頂硃 & & 24 & 0.24 \\
\hline Sutra binder & $\begin{array}{l}\text { Folding sutra } \\
\text { texts }\end{array}$ & 摺經 & & 20 folds & 0.16 \\
\hline $\begin{array}{l}\text { Coloured } \\
\text { lacquerer, gilder }\end{array}$ & & & & & 0.18 \\
\hline $\begin{array}{l}\text { Copyist for } \\
\text { printing (Song) } \\
\text { style characters }\end{array}$ & & & & $\begin{array}{l}100 \\
\text { characters }\end{array}$ & 0.03 \\
\hline
\end{tabular}

Source: Huidian, chap. 1199, fol. 10b. 
Table 39 Government wage rates for printing with wooden movable type for reprinting rare books of the 'Four Treasuries' project in the collectanea Wuying dian juzhenban [cong]shu, 1774

\begin{tabular}{lll}
\hline Work procedure & Work unit & Wage \\
\hline Carving the types & 100 types & 0.45 tael \\
Copying the characters (for carving Song-style types) & 100 types & 0.02 tael \\
\hline
\end{tabular}

Source: Huidian, chap. 1199, fol. 6 b.

Table 40 Wage rates for block printing in the provincial printery of Zhili, 1807

\begin{tabular}{|c|c|c|c|}
\hline Work procedure & $\begin{array}{l}\text { Work procedure in } \\
\text { Chinese }\end{array}$ & Unit & $\begin{array}{l}\text { Wage } \\
\text { in tael }\end{array}$ \\
\hline $\begin{array}{l}\text { Carving characters for judicial } \\
\text { protocols: New cases, in Chinese } \\
\text { characters }\end{array}$ & 刷印招冊, 刊刻新事漢字 & $\begin{array}{l}100 \text { characters } \\
\text { (new) }\end{array}$ & 0.044 \\
\hline $\begin{array}{l}\text { Carving characters for judicial } \\
\text { protocols: Previous cases, added at the } \\
\text { end, in Chinese characters }\end{array}$ & $\begin{array}{l}\text { 刷印招冊, 刊刻舊事後 } \\
\text { 尾漢字 }\end{array}$ & $\begin{array}{l}100 \text { characters } \\
\text { (old) }\end{array}$ & 0.065 \\
\hline $\begin{array}{l}\text { Correcting and emending old facts on } \\
\text { the blocks }\end{array}$ & 修補舊事漢字 & $\begin{array}{l}100 \text { characters } \\
\text { (repairing) }\end{array}$ & 0.12 \\
\hline $\begin{array}{l}\text { Planing the surface of old and new } \\
\text { printing blocks }\end{array}$ & 新舊板片刨面 & $\begin{array}{l}\text { One printing } \\
\text { block }\end{array}$ & 0.08 \\
\hline $\begin{array}{l}\text { Sawing the edges of old and new } \\
\text { printing blocks }\end{array}$ & 新舊板片鋸邊 & $\begin{array}{l}\text { One printing } \\
\text { block }\end{array}$ & 0.08 \\
\hline $\begin{array}{l}\text { Carving Manchu letters for new } \\
\text { Mongolian legal cases }\end{array}$ & 刻出蒙古案件新事清字 & $\begin{array}{l}100 \text { characters } \\
\text { (old) }\end{array}$ & 0.08 \\
\hline $\begin{array}{l}\text { Copying the red lines for the Chinese } \\
\text { characters in old and new legal cases }\end{array}$ & 繥寫新舊漢字紅格 & $\begin{array}{l}100 \text { characters } \\
\text { (old and new) }\end{array}$ & 0.01 \\
\hline $\begin{array}{l}\text { Copying the red lines for the Manchu } \\
\text { letters in Mongolian legal cases }\end{array}$ & 縉寫蒙古案件清字紅格 & $\begin{array}{l}100 \text { characters } \\
\text { Mongolian or } \\
\text { Manchu script }\end{array}$ & 0.13 \\
\hline $\begin{array}{l}\text { Printing the judicial protocols in } \\
\text { Chinese characters and the volumes } \\
\text { concerning Mongolian legal cases }\end{array}$ & $\begin{array}{l}\text { 刷印漢字招冊並蒙古事 } \\
\text { 件清冊 }\end{array}$ & 100 pages & 0.012 \\
\hline $\begin{array}{l}\text { Binding the judicial protocols in } \\
\text { Chinese characters and the volumes } \\
\text { concerning Mongolian cases }\end{array}$ & $\begin{array}{l}\text { 裝訂漢字招冊並蒙古事 } \\
\text { 件清冊 }\end{array}$ & 100 pages & 0.013 \\
\hline $\begin{array}{l}\text { Tracing margins for the yellow } \\
\text { volumes }\end{array}$ & 黃冊描邊 & 100 pages & 0.055 \\
\hline
\end{tabular}

Source: Peng Zeyi, Zhongguo jindai shougongye, vol. 1, pp. 407-408. 
Table 41 Government wage rates for copyists at the yushu chu, 1751 and 1795

\begin{tabular}{|c|c|c|c|c|c|}
\hline Year & $\begin{array}{l}\text { Status } \\
\text { group }\end{array}$ & Work procedure & $\begin{array}{l}\text { Work procedure } \\
\text { in Chinese }\end{array}$ & $\begin{array}{l}\text { Unit per } \\
\text { workload } \\
\text { gong }\end{array}$ & $\begin{array}{l}\text { Wage } \\
\text { in tael }\end{array}$ \\
\hline 1751 & $\begin{array}{l}\text { External, } \\
\text { hired artisan }\end{array}$ & $\begin{array}{l}\text { Copying printing ('Song') } \\
\text { style characters for the } \\
\text { transcript of the yearly } \\
\text { calendar Zhongxing genglu }\end{array}$ & 寫《中星更錄》宋字 & $\begin{array}{l}100 \\
\text { characters }\end{array}$ & 0.02 \\
\hline 1795 & $\begin{array}{l}\text { External, } \\
\text { hired artisan }\end{array}$ & $\begin{array}{l}\text { Copying printing ('Song') } \\
\text { style characters for the } \\
\text { transcript of the yearly } \\
\text { calendar Zhongxing genglu }\end{array}$ & 寫《中星更錄》宋字 & $\begin{array}{l}100 \\
\text { characters }\end{array}$ & 0.03 \\
\hline
\end{tabular}

Source: Huidian, chap. 1199, fol. 11b. The increase of 0.01 tael is expressly mentioned.

Table 42 External, hired artisans' wages for block printing in the Wuying dian, 1861

\begin{tabular}{|c|c|c|c|}
\hline Work procedure & $\begin{array}{l}\text { Work } \\
\text { procedure in } \\
\text { Chinese }\end{array}$ & $\begin{array}{l}\text { Unit per } \\
\text { workload gong }\end{array}$ & $\begin{array}{l}\text { Wage } \\
\text { in tael }\end{array}$ \\
\hline Carving/printing ('Song') style characters & 書刻宋字 & 100 characters & 0.08 \\
\hline $\begin{array}{l}\text { Carving standard handwriting ('soft') style } \\
\text { characters }\end{array}$ & 刻輭字 & 100 characters & 0.08 \\
\hline $\begin{array}{l}\text { Carving Ou-type handwriting style } \\
\text { characters }\end{array}$ & 刻歐字 & 100 characters & 0.14 \\
\hline $\begin{array}{l}\text { Carving Ou-type handwriting style } \\
\text { characters: above wage doubled if carved in } \\
\text { jujube wood }\end{array}$ & 刻歐字 & 100 characters & 0.28 \\
\hline $\begin{array}{l}\text { Carving out the white spaces in the printing } \\
\text { blocks and sawing the edges }\end{array}$ & $\begin{array}{l}\text { 剷除板片空地, } \\
\text { 鋸截板邊 }\end{array}$ & & 0.02 \\
\hline Carving illustrations & 刻畫圖 & $\begin{array}{l}\text { one square inch } \\
\text { per gong }\end{array}$ & 0.154 \\
\hline Copying/printing ('Song') style characters & 書寫宋字 & 100 characters & 0.02 \\
\hline $\begin{array}{l}\text { Copying standard handwriting ('soft') style } \\
\text { characters }\end{array}$ & 寫輢字 & 100 characters & 0.03 \\
\hline $\begin{array}{l}\text { Copying Ou-type handwriting style } \\
\text { characters }\end{array}$ & 寫歐字 & 100 characters & 0.04 \\
\hline Copying illustrations & 畫圖 & $\begin{array}{l}\text { two square } \\
\text { inch equals one } \\
\text { workload gong }\end{array}$ & 0.154 \\
\hline Folding and fixing the sheets & 摺配齊訂書籍 & 1,000 sheets & 0.13 \\
\hline Printing on fourfold Lianzhou paper & 印刷連四紙書 & 1,000 sheets & 0.16 \\
\hline
\end{tabular}




\begin{tabular}{|c|c|c|c|}
\hline Work procedure & $\begin{array}{l}\text { Work } \\
\text { procedure in } \\
\text { Chinese }\end{array}$ & $\begin{array}{l}\text { Unit per } \\
\text { workload gong }\end{array}$ & $\begin{array}{l}\text { Wage } \\
\text { in tael }\end{array}$ \\
\hline Printing on bamboo paper & 印刷竹紙書 & 1,000 sheets & 0.12 \\
\hline Cutting pages & 裁書 & 1,000 sheets & 0.02 \\
\hline
\end{tabular}

Source: Qinding zongguan Neiwufu xianxing zeli 欽定總管內務府現行則例 (Imperially endorsed current regulations and precedents of the Imperial Household Department). 1851-1861. Reprint Gugong zhenben congkan, vol. 309, p. 313.

Table 43 Wage rates for Wuying dian block printing projects of the $1870 \mathrm{~s} / 1880 \mathrm{~s}$

\begin{tabular}{|c|c|c|c|}
\hline Work procedure & $\begin{array}{l}\text { Work procedure in } \\
\text { Chinese }\end{array}$ & $\begin{array}{l}\text { Unit per } \\
\text { workload } \\
\text { gong }\end{array}$ & Wage in tael \\
\hline $\begin{array}{l}\text { Copying/printing ('Song') } \\
\text { style characters for the } \\
\text { transcript of the astronomical } \\
\text { work Xukan sanyuan jiazi } \\
\text { biannian wannian shu }\end{array}$ & $\begin{array}{l}\text { 繯寫《續刊三元甲子編年 } \\
\text { 萬年書》宋字板樣 }\end{array}$ & 100 characters & $\begin{array}{l}0.02 \text { plus food } \\
\text { allowance } 0.01\end{array}$ \\
\hline $\begin{array}{l}\text { Carving/printing ('Song') } \\
\text { style characters for the } \\
\text { Xukan sanyuan jiazi biannian } \\
\text { wannian shu }\end{array}$ & $\begin{array}{l}\text { 刻《續刊三元甲子編年萬 } \\
\text { 年書》宋字 }\end{array}$ & 100 characters & $\begin{array}{l}0.08 \text { plus food } \\
\text { allowance } 0.02\end{array}$ \\
\hline
\end{tabular}

Source: Liu Qiang, 'Qing Wuying dian', pp. 273-274, from the account books of the Wuying dian, Wuying dian xiushuchu zouxiao qingce 武英殿修書處奏銷清冊.

Table 44 Carving fees paid to the external printery Zhuanyun zhai in Peking, 1884

\begin{tabular}{lll}
\hline Work procedure & $\begin{array}{l}\text { Work proce- } \\
\text { dure in Chinese }\end{array}$ & $\begin{array}{l}\text { Norm wages for carving } 100 \\
\text { characters }\end{array}$ \\
\hline $\begin{array}{l}\text { Carving [soft-style] characters for } \\
\text { the palace regulations Gongzhong } \\
\text { xianxing zeli }\end{array}$ & $\begin{array}{l}\text { 刻《宮中現行則 } \\
\text { 例》[軟字] }\end{array}$ & $\begin{array}{l}0.24 \text { silver tael plus } 400 \text { copper } \\
\text { cash food and drink allowance } \\
\text { per day }\end{array}$ \\
\hline
\end{tabular}

Source: First Historical Archives document Neiwufu zeliguan 内務府則例館 23, Fuwen 附文 (Additional note) 1, and 3, p. 1-2. 
Table 45 Synopsis: Wages for copying 100 characters at the Wuying dian

\begin{tabular}{|c|c|c|c|c|}
\hline Year & Status group & $\begin{array}{l}\text { Norm wages in } \\
\text { silver tael }\end{array}$ & $\begin{array}{l}\text { Exchange } \\
\text { rate } 1 \text { tael } \\
\text { to copper } \\
\text { cash }\end{array}$ & Remarks \\
\hline 1705 & External, hired artisan & 0.04 & 1,400 & Soft style \\
\hline 1705 & External, hired artisan & 0.02 to 0.04 & 1,400 & Song style \\
\hline 1751 & External, hired artisan & 0.02 & 780 & $\begin{array}{l}\text { For the calendar Zhongxing } \\
\text { genglu }\end{array}$ \\
\hline 1768 & & 0.03 & 950 & Song style \\
\hline 1774 & & 0.02 & 955 & $\begin{array}{l}\text { For carving wooden movable } \\
\text { types, no running text }\end{array}$ \\
\hline 1795 & External, hired artisan & 0.03 & 1,150 & $\begin{array}{l}\text { Wage increase expressly } \\
\text { mentioned (Zhongxing } \\
\text { genglu) }\end{array}$ \\
\hline $1860 \mathrm{~s}$ & External, hired artisan & 0.02 & & Song style \\
\hline $1860 \mathrm{~s}$ & External, hired artisan & 0.03 & & Soft style \\
\hline $1860 \mathrm{~s}$ & External, hired artisan & 0.04 & & Ou style \\
\hline 1870 s & & $\begin{array}{l}0.02 \text { plus } 0.01 \\
\text { food allowance }\end{array}$ & & $\begin{array}{l}\text { For Xukan sanyuan jiazi } \\
\text { biannian wannian shu }\end{array}$ \\
\hline
\end{tabular}

Source: Tables 36, 38, 39, 41 to 43.

Table 46 Synopsis: Wages for carving 100 characters (government wage rates)

\begin{tabular}{|c|c|c|c|c|c|}
\hline Year & Status group & $\begin{array}{l}\text { Wages in silver } \\
\text { tael }\end{array}$ & $\begin{array}{l}\text { Exchange } \\
\text { rate }\end{array}$ & Institution & Remarks \\
\hline 1705 & $\begin{array}{l}\text { External, } \\
\text { hired artisan }\end{array}$ & 0.08 & 1,400 & W & Song \\
\hline 1705 & $\begin{array}{l}\text { External, } \\
\text { hired artisan }\end{array}$ & 0.14 to 0.16 & 1,400 & W & Soft style \\
\hline 1807 & $\begin{array}{l}\text { Civilian } \\
\text { artisan }\end{array}$ & 0.044 & $\begin{array}{l}970 \\
\text { (Ningjin) }\end{array}$ & $\begin{array}{l}\text { Zhili provincial } \\
\text { printery }\end{array}$ & New [blocks] \\
\hline 1807 & $\begin{array}{l}\text { Civilian } \\
\text { artisan }\end{array}$ & 0.065 & $\begin{array}{l}970 \\
\text { (Ningjin) }\end{array}$ & $\begin{array}{l}\text { Zhili provincial } \\
\text { printery }\end{array}$ & $\begin{array}{l}\text { Characters carved } \\
\text { on old [blocks] }\end{array}$ \\
\hline 1807 & $\begin{array}{l}\text { Civilian } \\
\text { artisan }\end{array}$ & 0.08 & $\begin{array}{l}970 \\
\text { (Ningjin) }\end{array}$ & $\begin{array}{l}\text { Zhili provincial } \\
\text { printery }\end{array}$ & Manchu letters \\
\hline 1861 & $\begin{array}{l}\text { External, } \\
\text { hired artisan }\end{array}$ & 0.08 & $\begin{array}{l}1,400-1,500 \\
(1855)\end{array}$ & W & Song style \\
\hline 1861 & $\begin{array}{l}\text { External, } \\
\text { hired artisan }\end{array}$ & 0.08 & $1,400-1,500$ & W & Soft style \\
\hline 1861 & $\begin{array}{l}\text { External, } \\
\text { hired artisan }\end{array}$ & 0.14 & $1,400-1,500$ & W & Ou style \\
\hline
\end{tabular}




\begin{tabular}{|c|c|c|c|c|c|}
\hline Year & Status group & $\begin{array}{l}\text { Wages in silver } \\
\text { tael }\end{array}$ & $\begin{array}{l}\text { Exchange } \\
\text { rate }\end{array}$ & Institution & Remarks \\
\hline $1870 s$ & & $\begin{array}{l}0.08 \text { plus } 0.02 \\
\text { food allowance }\end{array}$ & $\begin{array}{l}17,000 \\
(1875)\end{array}$ & w & Song style \\
\hline $\begin{array}{l}\text { Ca. } \\
1884\end{array}$ & $\begin{array}{l}\text { External, } \\
\text { hired artisans }\end{array}$ & $\begin{array}{l}0.24 \text { tael plus } \\
400 \text { cash food } \\
\text { and drink } \\
\text { allowance per } \\
\text { day }\end{array}$ & 16,250 & $\begin{array}{l}\text { Zhuanyun } \\
\text { zhai (Peking, } \\
\text { Liuli chang), } \\
\text { working in the } \\
\text { palace }\end{array}$ & $\begin{array}{l}\text { For Xianxing } \\
\text { gongzhong zeli. Soft } \\
\text { style. } \\
400 \text { cash food } \\
\text { allowance }=0.02 \text { tael }\end{array}$ \\
\hline \multicolumn{6}{|c|}{ For comparison } \\
\hline $1726-28$ & & 0.025 & 900 & w & $\begin{array}{l}\text { Carving one copper } \\
\text { movable type }\end{array}$ \\
\hline 1774 & & 0.45 & 955 & W & $\begin{array}{l}\text { Carving } 100 \text { wooden } \\
\text { movable types }\end{array}$ \\
\hline
\end{tabular}

W = Wuying dian

Source: Tables 36, 37, 39, 42 to 44 .

Table 47 Synopsis: Wages for printing 1,000 sheets (government wage rates)

\begin{tabular}{|c|c|c|c|c|c|}
\hline Year & Status group & $\begin{array}{l}\text { Wage in silver } \\
\text { tael }\end{array}$ & $\begin{array}{l}\text { Exchange } \\
\text { rate }\end{array}$ & Institution & Remarks \\
\hline 1705 & $\begin{array}{l}\text { Banner artisan } \\
\text { printer家內匠役 }\end{array}$ & $\begin{array}{l}0.1 \text { food } \\
\text { provision money }\end{array}$ & 1,400 & W & \\
\hline 1705 & $\begin{array}{l}\text { External, hired } \\
\text { artisan }\end{array}$ & 0.16 & 1,400 & W & $\begin{array}{l}\text { Printing on fourfold } \\
\text { Lianzhou paper }\end{array}$ \\
\hline 1705 & $\begin{array}{l}\text { External, hired } \\
\text { artisan }\end{array}$ & 0.12 & 1,400 & W & $\begin{array}{l}\text { Printing on bamboo } \\
\text { paper }\end{array}$ \\
\hline 1807 & Civilian artisan? & 0.12 & $\begin{array}{l}970 \\
\text { (Ningjin) }\end{array}$ & $\begin{array}{l}\text { Zhili } \\
\text { provincial } \\
\text { printery }\end{array}$ & $\begin{array}{l}\text { Wage given for } 100 \\
\text { pages }(0.012 \text { tael) }\end{array}$ \\
\hline 1861 & & 0.16 & $\begin{array}{l}1,400-1,500 \\
(1855)\end{array}$ & W & \\
\hline 1861 & & 0.12 & $1,400-1,500$ & W & \\
\hline
\end{tabular}

W = Wuying dian

Source: Tables 36, 40, 42.

Source for exchange rates: 'Exchange Rates Database' of the project group 'Monies, Markets, and Finance in China and East Asia 1600-1900', Tübingen University, Institute for Chinese and Korean Studies. 


\section{Table 48 Wage rates in commercial printing for carving 100 characters}

\begin{tabular}{|c|c|c|c|c|c|}
\hline Year & Place/Workshop & $\begin{array}{l}\text { Wage } \\
\text { in silver } \\
\text { tael }\end{array}$ & $\begin{array}{l}\text { Wage in } \\
\text { cash }\end{array}$ & $\begin{array}{l}\text { Exchange } \\
\text { rate }\end{array}$ & Source \\
\hline 1644 & $\begin{array}{l}\text { Peking, printer hired } \\
\text { by missionary Tang } \\
\text { Ruowang (Adam } \\
\text { Schall von Bell) }\end{array}$ & 0.06 & & 5,882 & $\begin{array}{l}\text { Tang Ruowang 湯若 } \\
\text { 望, Xiyang xinfa lishu } \\
\text { zoushu 《西洋新法 } \\
\text { 歷书奏疏》 }\end{array}$ \\
\hline $1662-1722$ & Peking & 0.08 & & $1,428-780$ & No source given \\
\hline 1773 & Peking, Wuying dian & 0.1 & & 955 & $\begin{array}{l}\text { Carving on pear } \\
\text { wood blocks }\end{array}$ \\
\hline $1790 s$ & & & $\begin{array}{l}\text { 56-63 coins } \\
\text { zhi-qian 制錢 } \\
\text { (official cash) }\end{array}$ & $1,060-1,150$ & No source given \\
\hline $\begin{array}{l}\text { Around } \\
1800\end{array}$ & Suzhou & & $110+$ & $\begin{array}{l}1,450 \\
(1799)\end{array}$ & $\begin{array}{l}\text { Wang Huizu 汗辉祖, } \\
\text { Bingta menghen lu 病 } \\
\text { 榻夢痕錄 }\end{array}$ \\
\hline Late 1870 s & Hunan, Yongzhou & & $50-60$ & & Shulin qinghua \\
\hline Mid 1880s & Hunan, Yongzhou & & $80-90$ & & Shulin qinghua \\
\hline Mid 1880s & $\begin{array}{l}\text { Hunan, Yongzhou, } \\
\text { Yuan-style script, } \\
\text { small }\end{array}$ & & 150 & & Shulin qinghua \\
\hline Mid 1880s & $\begin{array}{l}\text { Hunan, Yongzhou, } \\
\text { Yuan-style script, big }\end{array}$ & & 200 & & Shulin qinghua \\
\hline Mid 1880s & $\begin{array}{l}\text { Hunan, Yongzhou, } \\
\text { seal script per } \\
\text { character }\end{array}$ & & 5 & & Shulin qinghua \\
\hline Ca. 1910 & $\begin{array}{l}\text { Hunan, Yongzhou } \\
\text { (male wages) }\end{array}$ & & 130 & 1,600 & Shulin qinghua \\
\hline Ca. 1910 & $\begin{array}{l}\text { Hunan, Yongzhou } \\
\text { (female wages), but } \\
\text { also in Guangdong } \\
\text { and Jiangxi }\end{array}$ & & $20-30$ & 1,600 & Shulin qinghua \\
\hline
\end{tabular}

Sources: Zhang Xiumin, Zhongguo yinshua shi, p. 755; Ye Dehui, Shulin qinghua, pp. 154-155. 
